\title{
Katarzyna Majbroda
}

katarzyna.majbroda@uwr.edu.pl

Katedra Etnologii i Antropologii Kulturowej

Uniwersytet Wrocławski

\section{Wojciech Piasek}

piasek@umk.pl

Instytut Historii i Archiwistyki

Uniwersytet Mikołaja Kopernika w Toruniu

\section{ANTROPOLOGIA SPOŁECZNO-KULTUROWA W POLSCE DZISIAJ - DZIEDZICTWO, TERAŹNIEJSZOŚĆ, WYZWANIA I STRATEGIE NA PRZYSZŁOŚĆ. WOKÓŁ ANKIETY ANTROPOLOGICZNEJ}

\author{
Socio-Cultural Anthropology in Poland Today: Heritage, \\ Present Challenges, and Strategies \\ for the Future. Around an Anthropological Survey
}

\begin{abstract}
Streszczenie: Zawarte w tym tekście rozważania dotyczą kondycji współczesnej antropologii społeczno-kulturowej, jej celów i metod oraz obszarów badawczych, a także wyzwań, jakie stawia przed dyscypliną przyszłość. Rdzeń tego tekstu stanowi analiza odpowiedzi na ankietę antropologiczną zaty tułowaną Etnografia - etnologia - antropologia kulturowa dzisiaj. Cele, zakresy i praktyki badawcze oraz wyzwania na przyszłość, którą ogłosiliśmy w $2016 \mathrm{r}$. Obraz antropologii społeczno-kulturowej, jaki wyłania się w toku analizy, pokazuje wyraźnie, iż według uczestników ankiety antropologia powinna być krytyczną, kosmopolityczną dyscypliną, która szanuje różnicę, ale nie zgadza się na jej esencjalizowanie; dostrzegając i badając podobieństwa w różnych przestrzeniach rzeczywistości społeczno-kulturowej. Przyszłość antropologii to bycie dyscypliną zdolną do uprawiania krytyki refleksyjnej, adekwatną do tego, co aktualne. Antropologia przyszłości to dyscyplina, która ma w sobie imperatyw pobudzania społeczeństw i kultur, edukowania ich do współtworzenia społeczeństw otwartych. Ważnym zadaniem, jakie stawia przed antropolożkami i antropologami przyszłość, jest uspójnienie wizerunku dyscypliny na zewnątrz; w szeroko rozumianej komunikacji społecznej, co pozwoliłoby na wzmocnienie jej kapitału symbolicznego, który wydaje się szczególnie istotny z punktu widzenia celów i wyzwań, jakie stawiają przed antropologią jej przedstawicielki i przedstawiciele.
\end{abstract}


Słowa kluczowe: ankieta; antropologia społeczno-kulturowa; kapitał społeczny; fieldwork; wrażliwość społeczna i kulturowa; sprawczość; etyka; krytyka społeczno-kulturowa.

\begin{abstract}
The considerations in this text concern the goals, methods, challenges, and research areas of sociocultural anthropology both today and in the future. The text is centered around an analysis of responses to a 2016 anthropological survey entitled, Etnografia - etnologia - antropologia kulturowa dzisiaj. Cele, zakresy i praktyki badawcze oraz wyzwania na przyszłość (Ethnography, Ethnology, and Cultural Anthropology Today: Goals, Scope, Research Practices, and Future Challenges). Survey responses clearly indicated participants' opinion that anthropology should be a critical, cosmopolitan discipline that, in researching similarities between various sociocultural spaces, respects differences and does not essentialize. Future anthropology must be capable of reflective criticism of modern phenomena; a discipline whose imperative is to stimulate cultures, and to contribute to the creation of open societies through education. An important task facing subsequent generations of anthropologists is to unify the external image of the discipline in broadly defined social communication. This would help strengthen its social capital, which seems extremely important in terms of its goals and challenges.
\end{abstract}

Key words: survey; socio-cultural anthropology; fieldwork; social and cultural sensitivity; agency; ethics; socio-cultural critique.

Zawarte w tym tekście rozważania dotyczą odpowiedzi na ankietę antropologiczną zaty tułowaną Etnografia - etnologia - antropologia kulturowa dzisiaj. Cele, zakresy i praktyki badawcze oraz wyzwania na przyszłosś, którą ogłosiliśmy w 2016 r. w ra mach Sekcji Metodologicznej Polskiego Towarzystwa Ludoznawczego. Nawiązaliśmy w niej bezpośrednio do 1980 r., w którym Redakcja „Polskiej Sztuki Ludowej” rozesłała w środowisku etnologicznym ankietę, mającą na celu zdiagnozowanie ówczesnego stanu dyscypliny¹. Był to czas jej wyraźnego odchodzenia od ludoznawstwa i coraz bardziej uciążliwego etnografizmu, kiedy to przeobrażała się stopniowo, zachowując swój etnologiczny wymiar i jednocześnie antropologizując swoje perspektywy oraz podejścia badawcze. Zofia Sokolewicz w swoich rozważaniach wokół ankiety sprzed trzydziestu siedmiu lat pisała: „Definiowanie się nauki jest więc wyrazem konfrontacji. Nasilenie się pytań o definicję sygnalizuje więc zbliżanie się jakiegoś krytycznego punktu w owych konfrontacjach. Tak było w Polsce bezpośrednio po I wojnie światowej(Lud 1922) i na początku lat 30-ych (Lud 1932)" (Sokolewicz 1981: 78).

Ogłaszając ankietę, chcieliśmy także nawiązać do dobrej tradycji inspirowania środowiska naukowego do autorefleksji i metarefleksji, które pozwalają na krytyczne i cenne poznawczo przemyślenie aktualnego i przyszłego miejsca dyscypliny w nauce

\footnotetext{
${ }^{1}$ Ankietę rozesłano w połowie 1980 r., a odpowiedzi opublikowano w 1981 r. w „Polskiej Sztuce Ludowej" (Stomma 1981: 67).
} 
i poza nią, jej kapitału symbolicznego oraz celów, obszarów i metod badawczych, a także - co wydaje się aktualnie szczególnie ważne - etycznych oraz moralnych implikacji, które wiążą się z jej praktykowaniem.

Tożsamość antropologii powiązanej licznymi powinowactwami (analitycznokategorialnymi, problemowymi) z innymi dyscyplinami nauk humanistycznych i społecznych była już wielokrotnie dyskutowana; co nie oznacza, że jej przedstawicielki i przedstawiciele zdołali tę tożsamość w sposób jednoznaczny określić. Naszemu omówieniu ankiety towarzyszy przekonanie o potrzebie zmiany stawianych pytań, tak, by uzyskane odpowiedzi nie koncentrowały się wyłącznie na różnych konceptualizacjach istoty czy też esencji dyscypliny i sposobach uszczelniania jej naukowych granic, ale mogły przyczynić się do wypracowania jej spójnego wizerunku, rozpoznawalnego zarówno wewnątrz, jak i na zewnątrz nauki. Słowem, ważnym zadaniem środowiska antropologicznego w Polsce jest wypracowanie marki dyscypliny, która umożliwiłaby wykorzystanie jej kapitału symbolicznego do ważnych poznawczo i społecznie inwestycji.

Ankieta została rozesłana kilkukrotnie do szerokiego grona badaczek i badaczy praktykujących etnografię, etnologię i antropologię społeczno-kulturową. Zamierzaliśmy bowiem dowiedzieć się, jak są współcześnie postrzegane i rozumiane ich obszary badawcze, metody oraz cele - widziane i doświadczane zarówno przez ich przedstawicieli akademickich, jak i muzealników, pracowników skansenów, a także badaczki i badaczy, którzy sięgają do antropologii, czerpią inspiracje z jej wiedzy i doświadczeń badawczych, działając przy tym w ramach innych dyscy plin naukowych. Uzyskaliśmy 14 odpowiedzi, które przybrały rozmaite formy rozważań wokół zawartych w ankiecie pytań. Z inspiracji ankietą powstał artykuł Michała Buchowskiego Antropologia polska: genealogie, trajektorie ietyczne powinności (2017) publikowany w tym tomie, który podejmuje i rozwija między innymi wątki pojawiające się w pytaniach, znacznie je poszerzając. Rozważania antropologa na temat przeszłości, aktualnej kondycji i przyszłości dyscypliny włączamy do naszej analizy jako jeden z głosów wokół ankiety. Wszystkie uzyskane odpowiedzi, cenne i różnorodne refleksje na temat miejsca i roli dyscypliny we współczesnej rzeczywistości społeczno-kulturowej publikujemy w całości, zachowując autorskie style wypowiedzi. Zawarte w tym tekście uwagi dotyczące wyników ankiety mają charakter selektywny i aspektowy; koncentrują się bowiem wokół kwestii podejmowanych przez jej uczestników najżywiej. W celu zachowania toku i argumen- 
tacji autorek i autorów wybrane passusy z ich rozważań cytujemy w całości. Jaka jest zatem antropologia społeczno-kulturowa 'po polsku'?

\section{Co to jest etnografia/etnologia/antropologia (jej miejsce wśród innych dyscyplin, cele, metody)?}

Nawiązując do pytania zawartego w ankiecie „Polskiej Sztuki Ludowej”, zapytaliśmy: Co to jest etnografia/etnologia/antropologia (jejmiejsce wśród innych dyscyplin, cele, metody), nie sugerując myślenia o tych trzech nazwach w kategoriach etapów przeobrażania się jednej dyscy pliny, oddzielnych subdyscyplin czy też różnych wymiarów aktualnej kondycji antropologii kulturowej. Rozważania na ten temat, które w tym tomie publikujemy, pokazują wyraźnie, że wciąż żywe jest myślenie o etnografii i etnologii w kategoriach różnych nazw i podejść badawczych, które rezonują w antropologii kulturowej, przenikając się wzajemnie (Mariusz Filip, Marcin Lubaś, Karolina Zuba, Anna Malewska-Szałygin). Jak zauważa Zbigniew Jasiewicz:

Zbitka trójczłonowa w pytaniu i innych tekstach jest wynikiem długiej historii, co najmniej od XVIII wieku: potrzeb rozwoju nauki, inwencji i emocji badaczy, uwarunkowań lokalnych, presji ideologiczno-politycznej. Ta zbitka jest jednocześnie faktem współczesnym. My, profesjonaliści, jesteśmy z nią oswojeni. We właściwy nam sposób tłumaczymy znaczenie poszczególnych jej członów.

Z drugiej strony, równie wyraźne jest poczucie odrębności „tych trzech dyscyplin” (Janusz Barański, Wojciech Burszta, Michał Buchowski, Ewa Tomaszewska) oraz przekonanie wyrażone między innymi przez Katarzynę Kaniowską, która zaznacza, że mimo tego, iż zakresy tych nazw zazębiają się, nie jest uprawnione ich stosowanie jako określeń jednej dyscypliny ani też jako wyrazów bliskoznacznych czy synonimów. Jak zauważa badaczka:

[...] ścisły związek pomiędzy etnografią, etnologią i antropologią kultury raczej zakreśla horyzont poznawczy; daje możliwość, a nie jest koniecznością [...] w jakimś sensie - etnografia i etnologia pełnią funkcję służebną wobec antropologii kultury. Zachowując swą autonomię, poszerzają możliwości antropologii. Co znaczące, relacja pomiędzy wszystkimi tymi dziedzinami jest taka, że ze wszystkich trzech tylko etnografia nie potrzebuje pozostałych; etnologia i antropologia bez etnografii są nie do pomyślenia.

Z kolei Grzegorz Godlewski, wypowiadając się na temat specyfiki dyscypliny widzianej z perspektywy naukowca nieposiadającego, jak pisze, , profesjonalnego wy- 
kształcenia w tych dziedzinach", koncentruje swoje uwagi wyłącznie na antropologii, której wiedzę „uważa za podstawową w badaniach teoretycznych i wykorzystuje do konstruowania antropologicznej teorii kultury".

M. Buchowski zaznacza, iż termin 'etnologia' nie tak przekonująco jak 'antropologia' „wskazuje na szeroki zakres zainteresowań ludzi parających się kulturowo-społecznymi aspektami życia Człowieka”, zaś sama w sobie nazwa „sugeruje skupienie się raczej na grupach etnicznych, etniach czy etnosach, ich właściwościach kulturowych i przestrzennym zróżnicowaniu. Wyklucza też z pola skojarzeń antropologię biologiczną we wszelkich jej wcieleniach". Zdaniem Buchowskiego za uznaniem terminu 'antropologia' dla nazwy dyscypliny przemawia także fakt, iż jest on „najpowszechniej stosowanym terminem już nie tylko w krajach anglosaskich i nie ma sensu tracić sił w jałowych raczej sporach terminologicznych, których toczenie przypominałoby bitwy Don Kichota" (Buchowski 2017: 483).

Z. Jasiewicz podkreśla, iż współcześnie „etnografią” określa się metodę badań, a podwójna nazwa „etnologia/antropologia” nie jest dobrym rozwiązaniem komunikacyjnym, zatem spodziewa się, iż w przyszłości upowszechni się termin „antropologia". Badacz, podobnie jak Buchowski, formułuje pewne zastrzeżenia wobec uniwersalizującego użycia nazwy 'etnologia', akcentując nieco inne jej aspekty:

Etnologia, etymologicznie związana z greckim słowem ethnos, oznaczającym plemiona, ludy, narody, ale także zbiorowości, tłumy, rzesze połączone wspólnymi zwyczajami, $\mathrm{w}$ tradycji biblijnej przede wszystkim obce, pogańskie, nie żydowskie, jest tu słabszym członem. Narzuca węższy w porównaniu z „,antropologią" zakres badań związanych ze sprawami etnicznymi i dostrzeganymi poprzez nie różnicami kulturowymi. Dystans, obcość w stosunku do wskazywanych zbiorowości i społeczności, przypisany etnosowi w greckojęzycznej Biblii, właściwy był również dawnym etnologom, zainteresowanym odległymi ludami i traktującymi także własny „lud” jako odrębny i egzotyczny.

W kilku wypowiedziach zawarte zostały refleksje na temat ludoznawstwa, które pojawia się w komunikacji dyscyplinowej coraz rzadziej, funkcjonując, jak ma to miejsce w przypadku nazwy Polskiego Towarzystwa Ludoznawczego, jako forma zaświadczająca o określonych tradycjach tej instytucji. Z. Jasiewicz zwraca uwagę na fakt, iż „niewielu przedstawia się dziś jako ludoznawcy”, są to zwykle, jak dopowiada, „pasjonaci, często regionaliści, niezwiązani z instytucjami naukowymi, zainteresowani kulturą ludową". Zdaniem antropologa pojęcie 'ludoznawstwo' „będzie odnoszone i będzie odchodziło do historii, podobnie jak słowo 'lud' wiązane 
z przeszłością i uznane za nieprzystające do współczesnych wartości". Zdanie to podziela M. Buchowski, odnosząc się w swoim artykule do żywotności i zasadności lokowania ludoznawstwa w obrębie współczesnej dyscypliny, podkreślając przy tym, że o ile trudno byłoby uargumentować sensowność jego uprawiania w stylu badań ludu rozumianego w XIX-wiecznym sensie, o tyle ważne są badania „polegające na historycznych studiach nad klasą chłopską oraz tradycjami wiejskimi czy plebejskimi w zurbanizowanych obszarach". Zauważmy, dodaje antropolog, „że popularne w kręgu nowej etnologii polskiej badanie "kultury typu ludowego", której przedstawiciele garściami czerpali przecież z archiwów Kolberga i innych kolekcjonerów "starożytności słowiańskich " było także, skupionym na kulturze symbolicznej, unowocześnionym ludoznawstwem" (Buchowski 2017: 493).

W jeszcze inny sposób przywracanie ludoznawstwa współczesności widzi W. Burszta, który, odpowiadając na pytanie o miejsce historii w antropologii, zwraca uwagę na zjawisko „odpominania pamięci” dyscyplinowej, podkreślając, że „opowieść o narodzinach i dojrzewaniu polskiej etnografii abstrahowała dotąd od kwestii chłopskiego poddaństwa oraz zniewolenia. Obecnie objawia się ono w świetle teorii - no właśnie - postkolonialnych, chociaż baza źródłowa do tego istnieje od dziesięcioleci w ramach archiwum wiedzy $\mathrm{z}$ historii gospodarczej". Jak postuluje Burszta:

Historię polskiej etnografii trzeba w pewnym sensie napisać od nowa, uwzględniwszy to wszystko, co z niej było dotąd wypieranie w ramach - by znów odwołać się do nieodżałowanej pamięci M.R. Trouillot - uciszania pewnych aspektów przeszłości (niewolnictwo) kosztem uwypuklania wątków innych (chłopi jako „przechowalnik” rdzennej kultury).

W podobnych kontekstach rozważa ludoznawstwo Lubaś, który uważa, że etnologia jako określenie uznawane obecnie za synonim słowa antropologia, może również oznaczać ludoznawstwo studiujące kulturę ludową. W swojej argumentacji Lubaś podkreśla:

Jak wiadomo w niemieckiej tradycji naukowej istnieje opozycja między Völkerkunde (etnologią badającą społeczeństwa pozaeuropejskie) i Volkskunde (ludoznawstwem studiującym rodzimą kulturę ludową, chłopską). Opozycja ta wydaje mi się znacznie mniej wyrazista jeśli chodzi o Polskę. Tradycja ludoznawcza z wielu względów jest jawnie kontestowana przez niektórych badaczy i niektóre badaczki określających się jako etnolodzy/etnolożki/antropolodzy/antropolożki, ale nie jest jednak całkowicie przez środowisko etnologiczne odrzucana. 
Jednocześnie zauważa jednak, że w refleksji o ludoznawstwie polskim, niejako naturalnie, pojawia się pytanie o jego związki z „projektami narodowotwórczymi i polonizacyjnymi zarówno przed, jak i po drugiej wojnie światowej". Lubaś powtarza przytoczone wyżej rozpoznania dotyczące zasadności rewindykacji tych projektów dodając, że „unikanie refleksji na ten temat, gdy chodzi o etnologię i ludoznawstwo, byłoby równie błędne, co unikanie namysłu nad antropologią kolonialną i związkami antropologii z polityką imperialną".

Głosy te wydają się sprowadzać do propozycji krytycznej i rewindykacyjnej analizy dorobku ludoznawstwa w ramach polskich, środkowoeuropejskich badań postzależnościowych, które mogłyby zobaczyć w chłopstwie temat nieprzedawniony, zasługujący na ponowne analizy prowadzone wedle innego klucza, aniżeli kultura ludowa artefaktów i wierzeń; z uwzględnieniem kontekstów i kategorii politycznych, społecznych i ekonomicznych.

Za cechę idiomatyczną dyscypliny niezmiennie uznaje się prowadzenie badań empirycznych. Metoda etnograficzna jest konsekwentnie postrzegana jako nienaruszalny rdzeń dyscypliny, a także jako istotny element metodologii badań jakościowych. Jak zaznacza Katarzyna Kaniowska, jest to „jedyna wartość antropologii, która pozwala utrzymać jej tożsamość w grupie dyscyplin o takich samych lub daleko podobnych celach poznawczych oraz obszarze zainteresowań". Rozpoznanie to podzielają wszyscy uczestnicy ankiety, w rozmaity sposób wspomnianą metodę dookreślając. W wypowiedzi Tomasza Wojczaka etnografia kojarzona jest na przykład z opisem gęstym, rozpowszechnionym w antropologii przez Clifforda Geertza, który to koncept Wojczak uznaje za synonim etnografii. W refleksji M. Lubasia etnografia, oznaczająca „zbiór technik opisu życia ludzkiego opierających się na współuczestnictwie badacza/badaczki w określonych aktywnościach specyficznej grupy lub kategorii ludzi [...] jest stosowana w wielu naukach społecznych; wydaje się jednak nieodzowna w badaniach antropologicznych", co, zdaniem Lubasia, nie oznacza, iż „każdy antropolog/antropolożka musi osobiście prowadzić badania etnograficzne”, ale każdy adept antropologii „musi wszelako jako element nabywania wiedzy antropologicznej studiować opisy etnograficzne sporządzone przez innych badaczy/badaczki".

We wszystkich sformułowanych odpowiedziach etnografia sprowadzana jest do rozpoznawalnej metody, co zdaje się potwierdzać zasadność funkcjonowania poza dyscypliną określenia „etnograficzna metoda badań”, której tradycyjny rdzeń współ- 
tworzą obserwacja uczestnicząca, wywiad oraz bezpośredni kontakt z partnerami, uczestnikami badań, których po zwrocie refleksyjnym i etycznym coraz rzadziej określa się badanymi, a wyłącznie akcydentalnie informatorami. Jednocześnie, jak pisze Buchowski, potwierdzając rozpoznania uczestniczek/uczestników ankiety: „Etnografia, to nasze hołubione dziecko, zostało nam uprowadzone i nie jest w stanie wypełnić roli swoistego experimentum crucis. Zresztą definiowanie dyscypliny wyłącznie przez metodę jest raczej wątpliwym zabiegiem z teoriopoznawczego punktu widzenia" (Buchowski 2017: 494).

Metoda badań empirycznych, która w odpowiedziach ankietowych sprzed 37 lat ograniczała się do triady obserwacji, wywiadu i „dosłownej, fizycznej obecności" w terenie nie jest wystarczająca, by móc zdefiniować antropologiczne praktyki badawcze, ale przede wszystkim nie wyczerpuje różnych możliwych sposobów prowadzenia badań jakościowych. A. Malewska-Szałygin w swojej odpowiedzi zaznacza wprawdzie, iż badania terenowe polegające na obserwacji uczestniczącej to znak rozpoznawczy antropologów, dopowiada jednak, że:

W związku ze współczesną nierozdzielnością kontaktów bezpośrednich i zapośredniczonych cyfrowo do technik badawczych należy dołączyć obecność badacza realizowaną poprzez cyfrowe formy komunikacji (od telefonów komórkowych, smartfonów, przez Skype’a, fora i portale społecznościowe, po blogi, v-logi i inne).

J. Barański i M. Buchowski przywołują w tym kontekście ugruntowaną już w polskiej antropologii społeczno-kulturowej koncepcję etnografii wielostanowiskowej (multi-sited ethnography) George'a Marcusa, przypominając, że badania podejmowane w ramach dyscy pliny niejednokrotnie wymagają podążania za ludźmi, przedmiotami, metaforami, wątkami, historiami, alegoriami i biografiami (Marcus 1998: 90-94). Przyjmowanie wspomnianej metody badawczej z jednej strony, sprzyja holistycznej analizie zjawisk i pozwala na ich wieloaspektowe oświetlanie, z drugiej strony, wskazuje na dynamiczną naturę zjawisk, które współcześnie badamy oraz na ich rozproszenie przestrzenne.

Niezwykle nośnymi kategoriami, które poszerzają tradycyjny sposób rozumienia badań terenowych są „ doświadczenie”, „doświadczanie”, a także „ucieleśnione doświadczanie" rozumiane jako niezbędne elementy poznania, dzięki którym klasyczna metoda etnograficzna zostaje uzupełniona o elementy emocjonalne, sensoryczne, cielesne, zanurzające badaczkę/badacza w pozawerbalną, dzieloną z „tubylcami” 
rzeczywistość (Filip). Ten aspekt współczesnego poznania w antropologii podejmuje również A. Malewska-Szałygin, podkreślając, iż aktualnie obserwujemy:

[...]zwiększone zainteresowanie praktykami, „ucieleśnieniem” i cielesnością, doświadczaniem, materialnością, a także teorią afektu, emocjami oraz antropologią zmysłów rejestrującą kulturowo-społeczny wymiar zapachów, dźwięków, odczuwania środowiska (wpływów atmosferycznych) itp.

K. Kaniowska dostrzega w doświadczeniu jedną z najważniejszych kategorii, przekonując, iż na rzeczywistość w badaniach i analizach antropologicznych patrzymy jako na dziedzinę ludzkich doświadczeń. Jak pisze antropolożka:

Doświadczenie jest - w moim przekonaniu - kluczową kategorią we wszelkich interpretacjach antropologicznych. Tym samym można by powiedzieć, powtarzając za wieloma mistrzami antropologii, że antropologia jest nauką opisującą i tłumaczącą wielość i różnorodność sposobów rozumienia i przeżywania świata przez ludzi.

Z. Jasiewicz zaś podkreśla, iż w praktykowaniu dyscypliny ważną rolę odgrywa badacz, „obserwowani przezeń i odpytywani ludzie oraz teren, miejsce, w którym prowadzone są badania [...]”. Jednocześnie antropolog zwraca uwagę, iż:

Przedstawiciele posługują się wieloma innymi źródłami, które w konieczny sposób uzupełniają tradycyjną metodę etnograficzną, takimi jak ankieta, a także różnego rodzaju kwerendy zasobów źródeł zastanych: literatury, archiwaliów, zbiorów muzealnych, konieczne nie tylko przy opracowywaniu materiałów z badań terenowych, ale również przy przygotowywaniu ich programu.

Podobne rozumienie istoty praktykowania dyscypliny odnajdujemy w refleksji J. Barańskiego, który wielokrotnie podkreśla, że „etnolog za materiał bierze potoczne doświadczenia innych, co Michael Herzfeld określa jako "porównawcze badanie zdrowego rozsądku“ (2004: 9)”, a praca etnologa „polega na odkrywaniu niejako geologii owych doświadczeń i to z użyciem metod i technik nauk empirycznych." Expressis verbis wy raził to rozpoznanie M. Filip, pisząc:

Stoję na stanowisku, które reprezentują antropolodzy pokroju Edmunda Leacha, a obecnie Maurice'a Blocha, Kirsten Hastrup czy Judith Okely, że poznanie w antropologii nie odbywa się na poziomie języka, za pośrednictwem słów, lecz, niech będzie mi wolno powtórzyć własne słowa, „za sprawą ulotnego wyczucia, intuicji czy wrażliwości, powstających w toku osobistego, emocjonalnego, "cielesnego « doświadczania rzeczywistości społecznej". 
W podobnym tonie o roli etnologa w badaniu empirycznym wypowiada się Barański, eksponując jego „permanentną obecność w badanej rzeczywistości, intensywną z nią interakcję”, „bliską, czasem wręcz intymną, relację z badanym”. Powiązanie empirii z doświadczeniem w kontekście badań terenowych podkreśla także R. Statkiewicz, pisząc o „skupieniu się na praktyce, przebywaniu i wynoszeniu wiedzy z doświadczeń, rozmów i doznań".

Wypowiedzi te korespondują bardzo wyraźnie z coraz powszechniejszym $\mathrm{w}$ środowisku przekonaniem, że tym, co zajmuje antropolożki i antropologów najbardziej, jest rzeczywistość społeczno-kulturowa w jej codziennych, potocznych odsłonach; współtworzona przez praktyki społeczno-kulturowe, których nie sposób zrozumieć bez uwzględnienia kategorii doświadczania rzeczywistości, reflektowania o niej aktorów społecznych w powiązaniu z przemyśliwaniem własnych wyborów i pominięć metodologicznych oraz teoretycznych, a także zachowań i postaw w sytuacjach badawczych; słowem, bez bycia samoświadomym, sprawczym, frapującym (Kuligowski), odczuwającym mentalnie i cieleśnie podmiotem.

Przekonanie o znacznym potencjale poznawczym badań zwróconych ku doświadczaniu odnajdujemy także w refleksji G. Godlewskiego, który podkreśla jednak, że zwrot ku rzeczywistości i otwarcie na płynące z niej impulsy „musi kierować się wektorami bardziej konkretnymi”. Jak czytamy w rozważaniach kulturoznawcy:

Najbardziej przekonującą, moim zdaniem, propozycję w tym względzie przedstawił Victor Turner, który uznał, że perspektywę „żywych ludzi” najlepiej reprezentuje wymiar doświadczenia kulturowego. Jego koncepcja antropologii doświadczenia - traktowanej nie jako dział antropologii, tylko jako nowa jej postać, wyzwolona z ograniczeń podejścia systemowego - pozostała jednak otwartym projektem, niezrealizowanym również przez tych, którzy próbowali podjąć jego ideę. Rzecz w tym, że choć dość powszechnie uznaje się, iż bez uwzględnienia wymiaru doświadczenia - jak pisał Clifford Geertz - „każda analiza kulturowa wydaje się unosić kilka stóp nad ziemią”, to wymiar ten pozostaje w znacznej mierze niedostępny z zewnątrz i w związku z tym w niewielkim stopniu poddaje się operacjonalizacji badawczej.

Ostatnie zdanie przytoczonej wypowiedzi przypomina o trudnościach, jakie napotykamy, chcąc zachować lub wyeksponować doświadczeniowy, a zatem niejednokrotnie trudny do wypowiedzenia, wymykający się rozmaitym konceptualizacjom aspekt emocjonalnego i sensorycznego bycia w sytuacji badawczej, a także sposoby doświadczania rzeczywistości przez aktorów społecznych, tubylcze punkty widzenia przy jednoczesnej dbałości o teoriopoznawcze ambicje antropologii. Być może 
między innymi ta nieusuwalna trudność sprawia, że - jak wynika z rozpoznań zawartych w odpowiedziach na ankietę - w przestrzeni badań antropologicznych „coraz mniejszą rolę odgrywają regulacje teoretyczne” (Godlewski).

O doświadczający podmiot w pytaniach ankietowych słusznie upomniał się Z. Jasiewicz, zapytując: „Kim są etnografowie, etnologowie, antropologowie?”; dopowiadając:

Wprowadzam to uzupełnienie dlatego, aby podkreślić w nauce rolę czynnika pozanaukowego, jakim jest m.in. charakter badacza, przede wszystkim światopogląd, ale także indywidualne zdolności i preferencje. Światopogląd zajmujących się nauką, nieobojętny nawet w naukach formalnych, jest tym bardziej ważny w naukach empirycznych, społecznych i humanistycznych.

Autorefleksja, a może nawet autoetnografia, rozumiana nie tyle jako osobny nurt badawczy czy też oddzielny gatunek w piśmiennictwie antropologicznym, ale jako stały komponent praktykowania dyscypliny, stanowi istotny warunek bycia podmiotem świadomym moralnych implikacji poznania. M. Lubaś pisze o tym wprost, podkreślając, że „ważnym elementem etnograficznej pracy badawczej jest autorefleksja moralna, rozwój wrażliwości moralnej badaczy/badaczek pozwalającej bardziej zdecydowanie reagować na dobro i zło".

Autoidentyfikacja przedstawicieli środowiska wydaje się szczególnie istotna z punktu widzenia, podkreślanej przez ankietowanych, pilnej potrzeby rozpoznawalnej obecności antropolożek i antropologów w przestrzeni pozaakademickiej, a także uczynienia słyszalnymi ich głosów w debatach publicznych, które podejmują ważne, czasem wręcz palące, kwestie społeczne ${ }^{2}$. Mówimy wszak o dyscyplinie posiadającej ogromny kapitał symboliczny i znacznie mniej inwestycji przyczyniających się do jej rozpoznawalności w akademii, a zwłaszcza poza nią, w szeroko rozumianej komunikacji społecznej.

W większości wypowiedzi uczestniczek i uczestników ankiety wyraźnie rysuje się potrzeba ponownego przemyślenia, reinterpretacji i redefinicji nazwy dyscypliny, która zarówno w nauce, jak i w sferze publicznej funkcjonuje jako niedookreślona, niejasna i nie dość wyostrzona konceptualnie, by móc w jednoznaczny sposób

${ }^{2}$ Zagadnienie zaangażowania antropologii w rozwiązywanie problemów społecznych stanowi temat żywych dyskusji, w których ścierają się głosy i racje zwolenników oraz przeciwników tego stylu jej praktykowania. Dyskusje na ten temat podejmowane w ramach polskiej antropologii społeczno-kulturowej stanowią temat przewodni licznych publikacji. Zob. np. Brocki 2013; Rakowski, Malewska-Szałygin 2011. 
wskazywać na dyscyplinę i adekwatnie opisywać jej aktualną kondycję (Buchowski, Jasiewicz, Kaniowska, Kuligowski). W odpowiedzi na tę potrzebę uczestnicy ankiety tworzą definicje, czy też propozycje konceptualizowania antropologii, antropologii kulturowej, antropologii kultury oraz antropologii społecznokulturowej, zawierając w nich zarówno elementy tradycyjnego definiowania dyscypliny, jak i jej nowe aspekty, które pozwalają nakreślić, mówiąc za Paulem Rabinowem, antropologię aktualnego (anthropology today) $)^{3}$.

Osobiście nie mam wątpliwości co do naczelnej pozycji tej dyscypliny wśród nauk o człowieku - w sposób najbardziej ogólny, ambitny i fundamentalny rozumie pole swych badań, czego pośrednim dowodem są inspiracje, które pełnymi garściami czerpią z niej, zwłaszcza w ostatnich czasach, dyscypliny sąsiednie: od socjologii do literaturoznawstwa. W tym rozumieniu blisko jej nade wszystko do filozofii i to nie tylko z powodu wspomnianej rozległości zakresowej (Barański).

Antropologia jawi się jako nauka, która porównawczo i za pomocą metod etnograficznych nakierowanych na badanie życia ludzi w różnych kontekstach, ukazuje jedność człowieka jako istoty racjonalnej uwikłanej w życie społeczne, w którym w dynamicznej relacji uwarunkowań historyczno-strukturalnych i działających w nich sprawczych jednostek, tworzy się bezustannie zmieniające się formy kultury, stanowiące dla uczestników wydarzeń ramy odniesienia dla interpretacji sytuacji i podejmowania działań (Buchowski).

Zgadzam się w pełni z Michelem-Rolphem Trouillot, że w mocy pozostaje definicja antropologii społeczno-kulturowej jako otwartego zbioru praktyk i teorii, które podpadają pod starą formułę, iż anthropology is what anthropologists do (Burszta).

Dziś jedyną, jak sądzę, rzeczywistą antropologii wartością, która pozwala utrzymać jej tożsamość w grupie dyscyplin o takich samych lub daleko podobnych celach poznawczych i obszarze zainteresowań, jest metoda etnograficznych badań terenowych. Za cechę stanowiącą o tożsamości antropologii i różniącą ją od innych nauk uznaję również trwale $\mathrm{w}$ antropologii deklarowany przedmiot badań, jakim jest człowiek i jego kultura. Takie określenie przedmiotu pozwala na szersze i odmienne niż gdzie indziej rozpatrywanie kultury, bowiem w badanach i analizach antropologicznych

\footnotetext{
${ }^{3}$ Paul Rabinow wyprowadza koncepcję „antropologii aktualności” z ontologii aktualności Michaela Foucaulta (1984). W zamyśle antropologa dyscyplinę skoncentrowaną na tym, co aktualne cechuje perspektywizm poznawczy, antropologiczny namysł nad pojęciowymi konstrukcjami rzeczywistości, przy uwzględnieniu niezbywalnej praktyki pisania, w myśl założenia, iż „grafia ethosu, logosu i pathosu ustanawia uprzywilejowane miejsce badania i eksperymentowania" (Rabinow 2003: 77). Projekt anthropology today eksponuje aksjologiczny i moralny wymiar dyscyplinowej praxis, której, według Rabinowa, powinna towarzyszyć nieustanna refleksja o używanych pojęciach oraz kontekstach podejmowanych refleksji.
} 
patrzymy na nią jako na dziedzinę ludzkich doświadczeń. Doświadczenie jest w moim przekonaniu - kluczową kategorią we wszelkich interpretacjach antropologicznych. Tym samym można by powiedzieć, powtarzając za wieloma mistrzami antropologii, że antropologia jest nauką opisującą i tłumaczącą wielość i różnorodność sposobów rozumienia i przeżywania świata przez ludzi. (Kaniowska).

Pewien rdzeń dyscypliny można jednak opisać tak samo niemal, jak przed laty: antropologia to najbardziej ogólna ze szczegółowych nauk o człowieku, badająca sensy nadawane rzeczywistości przy użyciu metod empirycznych, gdzie grecki termin empeiria oznacza „doświadczenie” (Kuligowski).

[...] cechą szczególną antropologii jako nauki jest to, że jej przedmiotem są inne podmioty. Stąd [...] bierze się nastawienie na towarzyszenie badanym, opierające się na zawieszeniu wcześniejszych założeń poznawczych (w szczególności o charakterze paradygmatycznym) i przyjęciu postawy „uczonej niewiedzy”. [...] Jeśli w [...] konstelacji kierunków antropologia zachowuje odrębność - a moim zdaniem zachowuje i zachowywać powinna - to jej wyróżnikiem pozostają dwie właściwości: orientacja na Inność i Innego oraz opieranie się na badaniach terenowych, uznawanych, jak to określił James Clifford, za „praktykę dyscyplinującą” (Godlewski).

W moim przekonaniu antropologia zajmuje w ramach zachodniej nauki miejsce szczególne, a to dlatego, że jej celem jest poznanie Innego, a więc społeczeństw czy społeczności - tradycyjnie: pozaeuropejskich, współcześnie: jakichkolwiek - które pojmują świat w sposób od naszego odmienny, nierzadko radykalnie obcy (różnica stanowi sedno antropologicznego rozumienia kultury. [...] Osobiście uważam, że sednem antropologii i tym, co stanowi o specyfice tej dyscypliny, jest imperatyw kwestionowania (zachodniej) wiedzy naukowej (Filip).

Podwojona nazwa 'etnologia / antropologia kulturowa' nie jest jednak dobrym rozwiązaniem w komunikowaniu się wewnątrz środowiska naukowego i ze społeczeństwem. Być może zostanie ograniczona w przyszłości do 'antropologii'. Etnologia, etymologicznie związana z greckim słowem ethnos, oznaczającym plemiona, ludy, narody, ale także zbiorowości, tłumy, rzesze połączone wspólnymi zwyczajami (w tradycji biblijnej przede wszystkim obce, pogańskie, nie żydowskie), jest tu słabszym członem. Narzuca węższy w porównaniu z antropologią zakres badań związanych ze sprawami etnicznymi i dostrzeganymi poprzez nie różnicami kulturowymi. Dystans, obcość w stosunku do wskazywanych zbiorowości i społeczności [...]. Przezwyciężanie w naszych badaniach owego dystansu i zwrócenie się także ku swoim grupom i cechom wspólnym ludzkości, a nie tylko różnicom, może przemawiać na korzyść nazwy „antropologia” o szerszym zakresie. Nazwa ta musi być jednak wyposażona w odpowiedni przymiotnik czy przymiotniki ze względu na przynależność człowieka do wielu światów, nie tylko społeczeństwa i kultury, ale także natury, biologii (Jasiewicz). 
Antropologia to jedna z nauk zajmujących się człowiekiem. Przy tym zainteresowanie antropologii ludźmi jest zastanawiająco wszechstronne. Interesuje nas przeszłość, teraźniejszość i przyszłość człowieka, jego/jej historia i ewolucja, życie społeczne, psychiczne, biologiczne, środowiskowe, wariantywność sposobów ludzkiego życia w przestrzeni, modalności zmian, jakim ulega ono w różnych skalach czasowych. Antropologia była i jest nadal nauką poszukującą, stąd tak silny i nieprzerwany nacisk na wykorzystywanie intensywnych badań terenowych i etnografię w procesie tworzenia i kumulacji wiedzy antropologicznej. Nie należy - chociaż niekiedy tak czyniono - utożsamiać tego nastawienia na poszukiwanie z upodobaniem do egzotyki, pierwotności, archaiczności. Ważnym - może nawet najważniejszym - zagadnieniem w antropologii jest pytanie o przyczyny zmian, jakim ludzkie życie podlega, podlegało i podlegać będzie w całej jego kompleksowości i rozmieszczeniu na powierzchni Ziemi (Lubaś).

Etnologia / antropologia kulturowa i społeczna jest to dyscyplina naukowa przez Ministerstwo (MNiSW) umieszczana w obszarze nauk humanistycznych, choć większość etnologów jest zdania, że dziedzina ta plasuje się pomiędzy obszarem humanistyki i nauk społecznych. Etnologia to nauka badająca współczesne procesy kulturowo-społeczne (Malewska-Szałygin).

Na podstawie przeczytanych podręczników i licznych książek antropologicznych stwierdzam, że jedyną definicją antropologii i antropologii kulturowej, pod którą bym się podpisał, są słowa Tima Ingolda, który napisał, że: „Antropologia to filozofia z ludźmi w środku". [...] Antropologia kulturowa to królowa nauk humanistycznych i społecznych. Jest to swoista płaszczyzna, na której może dojść do realizacji marzenia Luciena Febvre’a i Marca Blocha, by stworzyć jedną ogólną naukę o człowieku, integrującą humanistykę i nauki społeczne (Wojczak).

Antropologia - szeroko rozumiana nauka o człowieku. Na tym poziomie dochodzi do „licznych” (ale i niezwykle potrzebnych!) podziałów na kategorie, takie jak: antropologia ekonomiczna, antropologia seksualności itp. Należy wspomnieć, że wszystkie z tych nurtów zajmują się „kulturą” lub „kulturami”, jednak niektóre z nich wprowadzają również czynniki i terminologię zapożyczone z biologii, czyniąc pojmowanie kultury wielopłaszczyznowym (Statkiewicz).

Antropologia kulturowa to nauka samorefleksyjna, której paradygmat bywa redefiniowany. Dostrzega ona uwarunkowania związane z własnymi ograniczeniami, z subiektywnością poznania, dostrzega znaczenie jego pozalogicznych elementów, które mają wpływ na rozumienie danego problemu, dopuszcza ambiwalencję i paradoks. Podkreśla dialogiczność czy wielogłosowość swojego podejścia, które odpowiada polifoniczności kultury w ogóle (Tomaszewska). 
Powyższe przykłady pokazują wyraźnie, że nazywając i dookreślając to, co wyróżnia antropologię i może decydować o jej rozpoznawalności, sięga się niezmiennie po zakorzenioną w niej metodę (etnografia, metoda porównawcza, badania empiryczne). Różnie rozumiany jest przedmiot oraz pola badawcze dyscypliny (Człowiek, jedność człowieka, podmioty, kultura, Inny/inność, odmienność, cechy wspólne ludzkości, sensy nadawane rzeczywistości, praktyki społeczno-kulturowe, wielość i różnorodność sposobów rozumienia i przeżywania świata przez ludzi). Różnie są również widziane jej wyraziste cechy (bywa porównawcza, samorefleksyjna, poszukująca, interpretująca, podważająca, rozumiejąca, wyjaśniająca, łącząca nauki humanistyczne i społeczne; bywa też królową nauk lokowaną w centrum dyscy plin ${ }^{4}$ ).

Przytoczone przykłady sposobów rozumienia dyscypliny, które stanowią zapewne wynik intersubiektywnych negocjacji ich autorek i autorów z klasycznymi ich postaciami, pokazują, że w polskiej antropologii trwałe, choć nie dominujące, jest tradycyjne myślenie o badanej rzeczywistości społecznej i kulturowej w kategoriach 'inności', 'odmienności' i 'różnicy'. W związku z tym nasuwa się pytanie, czy aby nie przeceniamy istotności i nieodzowności tych pojęć w procesie tłumaczenia teraźniejszości? Wydaje się, że warte rozważenia byłoby zwrócenie przez antropolożki i antropologów większej uwagi na podobieństwa, które właściwe są ludziom, procesom, praktykom kulturowo-społecznym bez względu na oczywiste różnice między nimi. Zapewne właśnie ten uniwersalny aspekt, nie zawsze uwzględniany w perspektywach antropologicznych, ma na uwadze Z. Jasiewicz, podkreślając, iż „przezwyciężanie w naszych badaniach owego dystansu i zwrócenie się także ku swoim grupom i cechom wspólnym ludzkości, a nie tylko różnicom" może przemawiać na korzyść nazwy „antropologia” o szerszym zakresie. Wspomniany aspekt podkreśla także M. Buchowski, przypominając, iż „antropologia jest przedsięwzięciem porównawczym”, a jej wyróżnikiem jest założenie o „uniwersalizmie przymiotów człowieczeństwa, ujawnianym przez pryzmat relatywizmu, czyli odkrywanie jedności w różnorodności", co znalazło wyraźną eksplikację w cytowanej powyżej definicji dyscypliny zaproponowanej przez antropologa (Buchowski 2017:495).

\footnotetext{
${ }^{4}$ Wydaje się, że obecnie wątek centralnego ulokowania dyscypliny w humanistyce nie jest tak eksponowany, jak jeszcze dekadę temu, kiedy zarówno przedstawiciele i przedstawicielki etnologii, antropologii, jak i innych dyscyplin podkreślali jej wpływ na reorientowanie się dyscyplin w stronę kultury i refleksji o niej (Pomieciński, Sikora 2009). Dzisiejsza antropologia zdaje się umacniać pozycję tzw. nowej humanistyki, przybierając postać humanistyki interwencyjnej, upominającej się o wyciszane wątki kulturowo-społecznego i politycznego urządzania rzeczywistości, a także wyjaśniającej konteksty oraz determinanty współczesnych zjawisk i procesów.
} 
Jednocześnie warto odnotować, że ankietowani w zdecydowany sposób odrzucają zasadność definiowania dyscypliny w kategoriach fascynacji tym, co egzotyczne. M. Lubaś podkreśla, że antropologia „była i jest nauką poszukującą”, „nie należy jednak utożsamiać tego nastawienia z upodobaniem do egzotyki, pierwotności, archaiczności". W. Kuligowski, rozważając przyszłość dyscypliny, wyraźnie akcentuje potrzebę „publikowania o sprawach dotyczących i obchodzących grona szersze niż te, które interesują się tanią egzotyką: czy to obcą, czy swojską". W takim samym tonie wypowiada się M. Buchowski, dopowiadając:

Wszak nie o bycie "handlarzami egzotyki” chodzi, o czym przekonywał dawno temu Roger Keesing (1989). To zadanie zostawmy podróżnikom, reportażystom i tym kulturoznawcom, którym tanie linie lotnicze umożliwiają nagle zachłystywanie się różnorodnością świata i powierzchowną refleksję o odległych ludach, praktykowanie „sztuki zadziwienia" inspirowanej kontaktem z odmiennością kulturową (Buchowski 2017: 496).

Wnioskując o popularności pewnych określeń na podstawie ich frekwencyjności w odpowiedziach na ankietę, nie sposób nie zauważyć, że zdecydowanie częściej „praktykujemy antropologię”, aniżeli ją „uprawiamy”. Komunikujemy także o metodach jako "praktykach badawczych" i poznaniu jako "praktykach poznawczych”; nie ulega również wątpliwości, że antropologiczna obserwacja jest skierowana na „praktyki społeczno-kulturowe”. Tendencja ta prawdopodobnie pokazuje zamierzoną, a czasem zapewne intuicyjną, potrzebę podkreślania działaniowego, sprawczego charakteru antropologii ${ }^{5}$, a także intelektualną atrakcyjność i społeczną użyteczność teorii praktyki w rozumieniu Pierre'a Bourdieu (2007).

Niezwykle istotne wydaje się podkreślenie, że odpowiedzi ankietowe pokazują, iż w dyskursach antropologicznych na dobre zadomowiły się pojęcia związane z porządkiem aksjologicznym, etyką oraz moralnością poznających podmiotów. W niemalże każdej z publikowanych poniżej wypowiedzi pojawia się „wrażliwość”, "doświadczanie”, „sprawczość”, „moralny imperatyw”; a co więcej, są one używa ne $\mathrm{w}$ odniesieniu do aksjologicznych implikacji poznania oraz do charakterystyki etosu antropolożek i antropologów. W szerszej perspektywie ich wyraźna obecność w dyskursach antropologicznych ostatnich lat zaświadcza o zmianie, jaka dokonała się w zakresie „dyscyplinowego temperamentu" - zdziwienie, kontemplacja i refleksja

\footnotetext{
${ }^{5}$ Diagnozowany styl praktykowania dyscypliny jest także zapewne wynikiem popularności i powszechności badań w działaniu (zob. Červinková, Gołębniak 2010), a także inspiracji płynących ze zwrotu performatywnego w dyscyplinie (zob. Rakowski 2013).
} 
ustępują coraz częściej diagnozowaniu, piętnowaniu, upominaniu się, działaniu, niezgadzaniu się, angażowaniu się oraz interwencji. Potwierdzają to zdecydowane opinie zawarte w refleksjach wokół pytań ankiety. Kwestia społecznego zaangażowania antropologii pojawia się także w refleksji G. Godlewskiego, formułowanej z zewnątrz dyscypliny, który, podkreślając potrzebę wyraźnego oddzielenia zaangażowania od poznawczego aspektu antropologii, pisze:

Nikt nie odmawia antropologom prawa do takich działań, również wykorzystujących wiedzę zdobytą podczas prowadzonych badań, ale działania te powinny być podejmowane poza samym postępowaniem badawczym, bo inaczej wiedza ta będzie naznaczona pozanaukowymi intencjami badacza i przez nie zniekształcona.

Z kolei zdaniem M. Buchowskiego, etyczny wymiar antropologii wymaga bezwarunkowego krytykowania wszystkich odmian nietolerancji. „Poglądy przeciwstawiające się tym fundamentalnym założeniom o jedności i równości wszystkich ludzi, antropologią nie są i lokują osoby je głoszące poza dyscypliną" (2017: 499). A. Malewska-Szałygin podkreśla działaniowy wymiar dyscypliny, zwracając uwagę, iż antropologia i antropolodzy podejmują działania na rzecz "propagowania idei otwartości i tolerancji, przeciwdziałania dyskryminacji i używania mowy nienawiści”. Antropolożka jako wyraźną cechę dyscypliny postrzega społeczne zaangażowanie na rzecz badanych, pisząc, iż antropolodzy często „angażują się w trudne problemy grup, które badają i aktywnie podejmują działania na rzecz poprawy ich sytuacji”.

Być może referowane wypowiedzi stanowią zręby klarującego się programu krytycznego antropologii społeczno-kulturowej, powstającego w reakcji przedstawicielek i przedstawicieli dyscypliny na niepokojące, wzrastające nastroje nacjonalistyczne, antysemityzm, ksenofobię, homofobię oraz mowę nienawiści obecną w różnych przestrzeniach życia. Polskie środowisko antropologiczne podjęło ten ważny temat w ramach Nadzwyczajnego zjazdu etnologów iantropologów polskich, który odbył się w Poznaniu 23 listopada 2016 r., wyrażając swój zdecydowany sprzeciw wobec tych niepokojących dyskursów i praktyk ${ }^{6}$.

\footnotetext{
${ }^{6}$ Zob. Manifest etnologów i antropologów polskich przeciw dyskryminacji, który ogłoszony został 23 listopada 2016 r. w Poznaniu podczas Nadzwyczajnego Zjazdu Etnologów i Antropologów Polskich. Dokument ten oraz wystąpienia wygłaszane podczas zjazdu są publikowane w tym tomie „Ludu”.
} 


\section{Jakie miejsce zajmuje w etnografii / etnologii / antropologii kulturowej problematyka badań nad przeszłością?}

Pytanie dotyczące miejsca, jakie zajmuje w etnografii, etnologii i antropologii kulturowej problematyka badań nad przeszłością, uruchomiło ponowną refleksję na temat umiejscowienia antropologii w strukturze akademickiej. Wśród odpowiedzi pojawiało się rozpoznanie o instytucjonalnym uwikłaniu dyscypliny, która w Polsce funkcjonuje najczęściej w ramach Wydziałów Historycznych, co wiąże się zarówno z ogólnym profilowaniem dydaktyki akademickiej, jej priorytetów oraz ograniczeń, jak i określoną polityką finansowania antropologicznych badań (Buchowski, Filip, Jasiewicz, Kuligowski). J. Barański zwraca uwagę, iż usytuowanie to jest wynikiem, jak to określa, „dawniejszego, historycznie nacechowanego paradygmatu”. Tymczasem dziś, kiedy zakresy, teorie, metody rodzimej etnologii poszerzają się o podejścia z porządku nauk społecznych, rodzi to wiele nieporozumień między antropologami, a większością historyków o „wrażliwości pozytywistycznej”. Jednocześnie etnolog zwraca uwagę na „rozziew wyobrażeń o etnologii, a tym, czym ona w istocie jest, którego ofiarą padają nawet sami koledzy akademicy zasiadający w radach wydziałów oraz - co gorsza - decydujący o misjach, strategiach, planach, finansach, doktoratach i habilitacjach".

Niefortunność lokowania dyscypliny w ramach nauk historycznych widoczna jest (i nierzadko boleśnie przez antropolożki i antropologów odczuwana) na przykład w polskich systemach grantowych, które przewidują realizację projektów antropologicznych w ramach modułów dotyczących „wiedzy o przeszłości” (Filip, Kuligowski).

$\mathrm{Z}$ racji instytucjonalnego umiejscowienia antropologii W. Kuligowski uznaje zadane pytanie za retoryczne, stwierdza jednak iż:

Na szczęście to tylko jedna warstwa struktury, będąca tyleż efektem akademickiej inercji, co i spuścizny po innym systemie ustrojowym. Kolejne warstwy - podejmowane badania, realizowane granty, tematyka zajęć dydaktycznych, tytuły publikowanych prac, tematyka organizowanych konferencji - pozwalają na myślenie o uwolnieniu się od bycia „nauką pomocniczą historii” [...] lub dyscypliną zorientowaną na „etnografię ratowniczą" i paradygmat ocalania. Tym, co wymaga ocalania i ratowania jest bowiem teraźniejszy stan kultury badanej przez antropologów. Przeszłość poradzi sobie sama, ma wszak innych, możniejszych patronów.

Wszystkie z analizowanych odpowiedzi podkreślają, iż wektor zainteresowań antropologicznych nakierowany jest na zjawiska, procesy, które mają miejsce współcześnie 
oraz na to, co rysuje się w przyszłości. Niemniej jednak przeszłość stanowi istotny element kontekstowej charakterystyki zjawisk oraz procesów, których zrozumienie byłoby z pominięciem uwarunkowań historycznych niemożliwe lub niepełne. Rozpoznanie to pojawia się w rozważaniach K. Kaniowskiej, która zauważa, iż „przeszłość jest przedmiotem badań o tyle, o ile jest ona konieczna do charakterystyki badanych zagadnień”. Rozwijając swoją myśl antropolożka dopowiada, iż:

Owo przesunięcie pól zainteresowań zmienia każdą z dziedzin. I tak etnografia zredukowana bywa do metody (mamy tego liczne przykłady w socjologii i kulturoznawstwie); etnologia staje się uzupełnieniem badań antropologii fizycznej czy archeologii (to z kolei widać w anglosaskich badaniach pozaeuropejskich lub projektach transdyscyplinarnych, których w Polsce wciąż brakuje); zaś antropologia skupiła się na problematyce pamięci.

Zdaniem Kaniowskiej to właśnie osadzone w przeszłości badanie pamięci przyniosło antropologii spore korzyści, zbliżając ją do innych dyscyplin humanistycznych, „wydobywając z niej potencjał tkwiący we wcześniejszym dorobku teoretycznym i metodologicznym oraz upowszechniając wiedzę o pamięci, jaką antropologia wytworzyła, zanim w humanistyce dokonał się "zwrot pamięciowy«".

Jeszcze inną strategię ukazania obecności aspektów historycznych w badaniach dyscyplinowych przyjmuje Z. Jasiewicz, który zaproponował wyodrębnienie kilku rodzajów tak sprofilowanych badań antropologicznych. Pierwszy z nich to badania nad „obecnymi w teraźniejszości śladami przeszłości oraz ich oceną i wykorzystaniem”. Ślady te występują pod różnymi postaciami i „zawsze są przez każdorazową współczesność przetwarzane; zachowane zostały albo tylko w pamięci, albo też nadal funkcjonują w społeczeństwie i kulturze, czasami - jeśli są źle oceniane - pod nazwą reliktów lub przeżytków". W oparciu o te badania zbudowana została znaczna część etnograficznej wiedzy o kulturze ludowej. Jak podkreśla antropolog:

Wiedza o kulturze ludowej (przymiotnik „ludowa” czyni z niej kulturę tradycyjną) jest zatem etnografią historyczną, uzupełnianą danymi dotyczącymi przetrwania i funkcjonowania elementów z przeszłości we współczesności badaczy. Do tego kierunku badań nawiązują studia nad tradycją, wykraczające poza zakres kultury ludowej, a także, tak ważne obecnie, studia nad dziedzictwem kulturowym. To, co dziedziczymy z przeszłości, pozytywnie wartościowane, określane jest jako dorobek przeszłych pokoleń, najchętniej przodków, pomniki albo skarby przeszłości. Sięgamy po nie, przystosowujemy do współczesnego życia i użytkujemy jako współtworzące naszą wyróżniającą się tożsamość, zagrożoną globalizacją. [...] Drugi kierunek 
stanowią badania, które przeszłość i teraźniejszość przedstawiają jako jeden nurt wydarzeń, w którym to, co było dawniej współtworzy współczesne życie społecznokulturowe i pozwala je wyjaśnić. Są to studia historyczno-etnograficzne, dzisiaj mniej już popularne [...]. Wreszcie ostatni wyróżniony przeze mnie rodzaj studiów traktuje przeszłość jako byt autonomiczny, który staramy się poznać, stosując metody antropologiczne. W jego ramach antropolodzy traktują źródła historyczne jakby były jego rozmówcami i stawiają im antropologiczne pytania.

Znaczenie tych ostatnich badań potwierdza, zdaniem Jasiewicza, antropologizacja historii. Elementy tych trzech rodzajów studiów występują w badaniach nad historią samej dyscypliny, która stanowi w tej typologii kolejny obszar, na którym antropolog napotyka w swoich badaniach przeszłość. Z. Jasiewicz kończy wypowiedź uwagą, iż „etnologia / a ntropologia kulturowa nie jest nauką historyczną, jej głównym przedmiotem jest współczesność badacza, nie powinna jednakże rezygnować ze swoich kompetencji zajmowania się przeszłością. To one tworzą jedną z jej cech i stanowią o jej tożsamości”.

Na marginalizację w polskiej antropologii problematyki badań nad przeszłością zwraca uwagę T. Wojczak, dostrzegając potrzebę uzupełnienia dydaktyki z zakresu etnologii o historię jako naukę pomocniczą, która mogłaby, jego zdaniem, pojawić się w programie studiów razem z łaciną. Relacje antropologii z historią żywo zajmują również M. Filipa, który dostrzega nikłą obecność refleksji historycznej w dyscyplinie i jak podkreśla: „dzieje się to ze szkodą zarówno dla antropologii, jak i historii”. Podobnie jak poprzednicy, Filip wiąże ten typ zainteresowań z tzw. nową etnologią polską, zwaną antropologią kultury, która mimo znaczących osiągnięć „nie zdołała jednak wypracować programu antropologicznego sensu stricto”. Popularności antropologii kultury Filip dopatruje się głównie w jej interdyscyplinarnym i eseistycznym charakterze, który decydować miałby także o jej atrakcyjności dla środowiska historyków związanych (w przeszłości i obecnie) z czasopismem „Rocznik Antropologii Historii”. W tym kręgu dokonuje się współcześnie antropologizacja historii za pomocą antropologii kultury, którą M. Filip określa jako „antropologizację historii antropologizującą historią”. W krytycznym oglądzie osiągnięć wspomnianego nurtu antropolog podkreśla dokonania „starej” etnologii K. Moszyńskiego, A. Dobrowolskiej czy też B. Stelmachowskiej. Zdaniem Filipa ciekawe poznawczo są współczesne prace osadzone w antropologii kulturowej, dotyczące weryfikacji statusu i historii grup zamieszkujących peryferia ziem polskich oraz zachodnią Amazonię, a także opracowania systematyzujące zróżnicowanie kulturowe Ameryki Środkowej i Południowej. M. Filip wskazuje również na ważność dyskusji polskich 
antropologów zainteresowanych studiami nad początkami państwa z dokonaniami historykówi archeologów. W referowanej wypowiedzi bodaj największy antropologiczny obszar badawczy skoncentrowany na historii tworzą „badania lokalnych wyobrażeń na temat historii oraz pamięci, jakie właściwe są różnym grupom etnicznym", a także rozmaitym grupom społecznym; badania rekonstrukcji historycznych oraz lokalnych użyć dokumentów, pomników. Zaletą tych badań jest przedstawianie historii z punktu widzenia aktorów społecznych. Jak podsumowuje antropolog:

$\mathrm{W}$ istocie, polscy antropolodzy coraz częściej mierzą się z problematyką badań nad przeszłością w sposób, który bezpośrednio nawiązuje do dokonań światowej antropologii na polu studiów etnicznych i ekonomii politycznej, czyniąc swoim głównym przedmiotem dociekań tożsamość grup etnograficznych czy, mówiąc innymi słowy, ich historycznośćwobuznaczeniach tego słowa: „obiektywnej” realnościw procesie historycznym i „subiektywnego" (kulturowego) sposobu postrzegania procesów historycznych.

Istotną rolę przeszłości w badaniach antropologicznych dostrzega również M. Lubaś, zwracając uwagę, iż dzięki znajomości przeszłości i wiedzy historycznej antropolog może pytać o naturę i przebieg zmian, jakim podlega człowiek. Badacz eksponuje rolę, jaką historia odegrała w przemianach zachodzących w dyscyplinie, pisząc:

Zaryzykowałbym zdanie, że to właśnie historia społeczna pozwoliła antropologii wykroczyć poza ramy teorii społeczeństwa pierwotnego i poważnie zainteresować się zmianami społecznymi, zarówno zachodzącymi bardzo powoli (błędnie określanymi mianem procesów reprodukcji społecznej), jak i też tymi, które postępują znacznie szybciej i gwałtowniej.

Podobne stanowisko zajmuje Buchowski, który, jak pamiętamy, definiując antropologię pisze o „badaniu człowieka uwikłanego w życie społeczne z jego dynamiczną relacją uwarunkowań historyczno-strukturalnych i działających w nich sprawczych jednostek". Ponadto Lubaś zauważa, iż antropologia poszukując źródeł, chętnie sięga do historii mówionej, wizualnej oraz popularnej, a także „wydaje się szczególnie uwrażliwiona na to, iż przeszłość podlega na bieżąco narratywizacji i że narracje historyczne wywierają ogromny wpływ na przebieg zdarzeń, a zatem również na przyszłość ludzkości”.

Na jeszcze inną kwestię zwraca uwagę A. Malewska-Szałygin, która, rozważając rolę badań nad przeszłością podejmowanych w dyscyplinie, zauważa, iż „przeszłość jest współcześnie wykorzystywana jako rodzaj rekwizytorni do tworzenia nowych konstruktów tożsamościowych". Jak przekonuje antropolożka: 
Elementy przeszłości, wyrwane z kontekstu i zestetyzowane (lub w inny sposób dostosowane do aktualnych wymogów) służą do wytwarzania wizerunków na potrzeby obecnego „supermarketu kultury” [...]. Wizerunki indywidualne, grupowe, regionalne, etniczne, narodowe prezentowane są w rzeczywistości doświadczanej bezpośrednio (muzea, skanseny, aranżacje kwater agroturystycznych [wnętrza, stroje, potrawy], konkursy, festiwale folklorystyczne, wydarzenia kulturalne, koncerty itp.).

W zarysowanym kontekście ciekawe poznawczo wydają się wypowiedzi, w których prezentowana jest perspektywa muzealników oraz pracowników skansenów. Jak podkreśla E. Tomaszewska, w ramach instytucji muzealnej typu skansenowskiego, wpisane w etnologię badania nad przeszłością, „swoiste rekonstrukcje” odgrywają szczególną rolę. „Duże znaczenie mają tu studia społeczności regionalnych z szerokimi odwołaniami do kultury tradycyjnej, które postrzegane są jako istotne dla współczesnego regionalnego życia kulturalnego i lokalnej tożsamości”. Podobne rozpoznanie pojawia się w refleksji K. Zuby pracującej w Muzeum Budownictwa Ludowego w Sanoku, która eksponuje naturalny charakter wpisanego w tę profesję nieustannego sięgania do historii, pisząc:

Specyfika muzeum sprawia, że badania nad przeszłością zajmują bardzo ważne, jeśli nie kluczowe miejsce we wszelkich jego działaniach. Etnograficzne techniki badawcze (wywiady, obserwacje) oraz gromadzenie i naukowe opracowywanie zbiorów etnograficznych pozwalają w znacznym stopniu rekonstruować zanikające już elementy dawnej kultury ludowej, miejskiej czy też szlacheckiej (dotyczy to zarówno kultury materialnej, jak i sfery duchowej oraz społecznej). Prowadzone przez pracowników MBL badania pomagają umiejscowić eksponaty w odpowiednim kontekście kulturowym i historycznym, co pozwala na odpowiednie tworzenie ekspozycji. Dzięki temu zwiedzający mają okazję zapoznać się nie tylko z historią regionu, ale i jego dawną kulturą. Oczywiście nie jest to jedyny sposób uprawiania przez pracowników $\mathrm{Mu}$ zeum etnografii. Kolejne ważne działania to dokumentacja otaczającej rzeczywistości (która przecież kiedyś stanie się przeszłością).

W odpowiedzi W. Burszty badanie przeszłości dyscypliny projektowane jest jako nurt „wiwisekcyjny”. Wzrostu jego znaczenia w antropologii Burszta upatruje w „pogłębiającej się tendencji do krytycznego mierzenia się zarówno z historią samej antropologii, jak i historią świata widzianą przez pryzmat kolonializmu, którego antropologia - chcąc tego czy nie - była elementem”. Co więcej, antropolog podkreśla, że „odpominanie przeszłości nie tylko ma moc wyzwalającą, ale pozwala zrozumieć, dlaczego antropologia nigdy nie była niewinną, bezinteresowną i apolityczną 
wiedzą [...]. To ważne dla dzisiejszej samoświadomości także i dlatego, że wyznacza inną trajektorię opisu historii kultury jako praktykowania kapitalizmu w ramach promowania kultury euroatlantyckiej”. W rodzimym kontekście wspomniane „odpominanie" przeszłości wiąże się ze zmianą optyki postrzegania dziejów polskiego ludoznawstwa i koniecznością napisania od nowa historii polskiej etnografii, w której należałoby uwzględnić to wszystko, co było z niej dotąd wypierane.

Odwoływanie się w badaniach i refleksjach antropologicznych do przeszłości bywa zatem rozumiane jako szansa dyscypliny na przepracowanie zagadnień, które z punktu widzenia dzisiejszej krytycznej, post-zależnościowej świadomości oraz istnienia teorii i narzędzi przydatnych w procesie rewindykacji i reinterpretacji tych zjawisk, mogłyby zostać wytłumaczone i przedstawione na nowo. To z kolei zachęca do postawienia pytania o zasadność i potrzebę pojawienia się w dyscyplinie nurtu post-ludoznawstwa, a może także post-etnografii, w ramach których mogłyby na przykład powstawać krytyczne i jednocześnie emancypujące studia nad społecznościami, wspólnotami oraz procesami, które w tradycyjnych badaniach etnograficznych i ludoznawczych zastygły w zmitologizowanych, nierzadko zideologizowanych formach.

\section{W jakim stopniu możemy współcześnie mówić o dominujących stylach praktykowania antropologii; czy można by wskazać nurty i orientacje badawcze o charakterze paradygmatycznym?}

W odpowiedziach na to pytanie bardzo wyraźnie zarysowało się rozpoznanie, iż zagadnienie to można przedstawić w szerszej perspektywie czasowej. Powiedzmy, że do wczesnych lat 90. antropologią rządziły paradygmaty (kilka z nich, np. strukturalizm, fenomenologia, hermeneutyka nawet w Kuhnowskim znaczeniu). Można by powiedzieć, upraszczając rzecz znacznie, że wraz z dynamicznymi przejściami strukturalizmu w poststrukturalizm, hermeneutyki w interpretatywizm i fenomenologii w nurt doświadczeniowy, wraz z pojawieniem się w dyscy plinie kolejnych zwrotów: tekstualnego, literackiego, etycznego, postmodernistycznego, interpretatywnego, refleksyjnego, performatywnego, afektywnego, ontologicznego i jeszcze kilku inny czekających na nazwanie, trudno byłoby poszukiwać w antropologii orientacji o charakterze wiodącym, paradygmatycznym. Rozpoznanie to podzie- 
lają wszyscy uczestnicy ankiety, umieszczając tę diagnozę w szerszym kontekście zmian, jakie zaszły w antropologiach światowych ostatnich dekad.

J. Barański zauważa, iż jeszcze „wiek XX w antropologii pozostawał pod znakiem wielkich teorii z jednej strony, z drugiej zaś, drobiazgowej aktywności empirycznej”. Jak podkreśla:

Dziś wskazuje się na szczególny stan antropologii współczesnej - between-betweex - pomiędzy teorią a praktyką, ogólnym a szczegółowym, globalnym a lokalnym, diachronią a synchronią, akademicką pracą analityczną a codziennym zaangażowaniem. Nikt przy tym nie przykłada szczególnej wagi zarówno do wznoszenia gmachów owych wielkich teorii, jak i prowadzenia stacjonarnych i totalnych badań terenowych.

W. Burszta wiąże tę diagnozowaną postparadygmatyczność antropologii z „poetyką kolejnych zwrotów", które wpływają na sposoby praktykowania dyscypliny. Jak konstatuje:

Antropologia jest dzisiaj zarażona poetyką kolejnych „zwrotów” teoretycznych, które wyznaczają puls badań. Ale żaden z nich - od refleksyjnego, przez piktorialny, pamięciowy, neuronaukowy czy jakie tam jeszcze się pojawiają, nie jest w stanie zdobyć dominującej pozycji. Żyjemy w stanie całkowitego rozproszenia pod tym względem. Jak się wydaje, wiąże się to ściśle ze słabnącą rolą humanistyki w neoliberalnej koncepcji świata. Walczymy o byt, walczymy o kurczące się środki i działamy zadaniowo, zgodnie z logiką grantowo-projektową. To nigdy nie sprzyja rozwojowi bardziej pogłębionej refleksji, niestety. Ale nie oznacza to, że ona nie istnieje; ginie jednak w codziennej krzątaninie i walce o przetrwanie.

Odmiennie od zamieszczonych powyżej wypowiedzi zjawisko różnorodności stylów praktykowania rodzimej antropologii widzi Kuligowski, który koncentruje się na epistemologicznych podstawach dyscypliny, dostrzegając w niej wyraźne pozostałości zdyskredytowanego pozytywizmu. Jak podkreśla antropolog:

Jedynym paradygmatem, który z powodzeniem przyswoiła polska etnologia/antropologia jest pozytywizm i postpozytywizm. To rzutuje na dominację obiektywistycznego modelu poznania, korespondencyjnej koncepcji prawdy oraz przekonania o istnieniu neutralnych opisów i adekwatnego języka reprezentacji. Doniosłe zwroty - relatywistyczny, etyczny, postmodernistyczny - zostawiły pojedyncze i nieciągłe ślady.

G. Godlewski w swojej refleksji zauważa, iż antropologia od początku była nauką wieloparadygmatyczną, zaznaczając jednocześnie, iż „siła ortodoksji niektórych z nich była potężna". Jak przekonuje kulturoznawca, sytuacja uległa zmianie wraz z tym, jak 
[...] zaczęto sobie zdawać sprawę, iż model paradygmatyczny - dyktujący „zstępujący” porządek poznania, zgodnie z którym ogólna teoria wyznacza nie tylko metody i cele badań, ale również sposób definiowania tego, co może stać się ich przedmiotem - prowadzi do poważnych ograniczeń i zniekształceń poznawanej rzeczywistości. Podejście systemowe pozostawia poza swoim zasięgiem w szczególności to, co składa się na realne życie kultury - co jest udziałem [...] „żywych ludzi”. Porządek „zstępujący” jest więc coraz częściej zastępowany przez porządek „wstępujący”, zgodnie z którym badacze, rezygnując ze wsparcia teorii paradygmatycznych, w pierwszym kroku otwierają się na wyzwania poznawcze samej rzeczywistości kulturowej i dopiero po rozpoznaniu napotkanych zadań konstruują swoje stanowisko badawcze ze składników dobranych stosownie do ich specyfiki, nie zaś z uwagi na jakąkolwiek ortodoksję teoretyczną czy dyscyplinarną.

Rozpoznanie to podziela Z. Jasiewicz, zauważając, że dziś trudno byłoby mówić o dogmatycznym i ekskluzywnym traktowaniu pojawiających się nowych kierunków teoretycznych. W taki właśnie sposób były postrzegane w przeszłości polskiej antropologii, co wynikało z „atmosfery zmagań z tradycyjną etnografią, czy też, choćby w pewnym stopniu, przejętej z systemu totalitarnego potrzeby wspierania się monolityczną konstrukcją myślową i stojącym za nią autorytetem osobowym. [...] Czas podobnego postępowania minął, było ono jednak chyba nieuniknione, a jego następstwa w pewien sposób pożyteczne. Zwróciło uwagę na znaczenie teorii”.

M. Lubaś, zastanawiając się nad antropologicznymi sposobami poznania, sygnalizuje kilka linii podziału współczesnej dyscypliny. Jak zauważa, zarówno w wymiarze „przedmiotu” badania, jak i sposobu uprawiania antropologii wciąż istotne są różnice regionalne. Poza tym ważne kryterium podziału stanowią postępujące zróżnicowania między subdyscyplinami antropologii. Jako ostatnie kryterium wskazuje zróżnicowanie założeń filozoficznych, które, jak zaznacza:

[...] czasami mają znaczenie drugorzędne i nie hamują wzajemnego przepływu idei; bywa jednak, że różnice są na tyle istotne, że prowadzą do trwalszych odmienności w praktykowaniu antropologii. Różnice takie występują np. między nurtami silnie anty-redukcjonistycznymi czerpiącymi z post-strukturalizmu oraz równie mocno redukcjonistycznymi odwołującymi się do biologii ewolucyjnej.

Obraz zróżnicowanej wewnętrznie dyscypliny zawarty jest także w artykule $\mathrm{M}$. Buchowskiego, który przekonany jest o tym, iż dzisiejsza antropologia to „różni ludzie i różne antropologie". Dokonując przeglądu tych zróżnicowanych obszarów badawczych, przyjmuje za jego kryterium wskazanie takich nurtów, które wyróżniają naszą „narodową" tradycję i zarazem włączają się potencjalnie w wymiar powszechny antropologii. 
Pierwszy z nich to „kontynuacja studiów z zakresu teorii antropologicznych.[...]Mieszczą się tu między innymi spory o uniwersalizm i partykularyzm kultur, o strukturalizm i postmodernizm, o antropologię scjentystyczną i interpretacyjną, względnie refleksyjną, oraz komentujące kolejne "zwroty « $\mathbf{w}$ antropologii". Drugi związany jest $\mathbf{z}$ mocną obecnością „nurtów fenomenologicznego i hermeneutycznego. [...] Fenomenologia w dość oryginalny sposób wzmocniona została inspiracjami płynącymi z hermeneutyki, co przyniosło kilka naprawdę interesujących dzieł" (Buchowski 2017: 489).

$\mathrm{Na}$ wiodący charakter inspiracji fenomenologicznych w badaniach praktyk społeczno-kulturowych zwraca także uwagę Godlewski, podkreślając, że nie chodzi w nich o „bezpośrednią aplikację fenomenologicznego stanowiska filozoficznego, tylko o takie jego przekształcenie, by pozwalało docierać do tego, jak świat Innych jawi się im samym (nie zaś badaczowi czy innemu uniwersalizowanemu podmiotowi)". Trzeci obszar wymieniony przez Buchowskiego to studia nad postsocjalizmem:

[...] które w antropologiczny sposób problematyzowały zagadnienie zachodzących zmian społecznych i kulturowych. Mieściły się tu - na przykład - badania klas społecznych i ich kulturowych wyobrażeń, ubóstwa czy płci kulturowej - wszystkie zagadnienia widziane w perspektywie ekspansji neoliberalnego kapitalizmu na obszary zdominowane uprzednio przez reżimy komunistyczne. Dziś za ich kontynuację uznać można analizy przyczyn i mechanizmów reakcji ksenofobicznych, w szczególności agresywnego nacjonalizmu (2017: 489).

W swoich rozważaniach na temat wyraźnie wyklarowanych dziedzin współczesnych badań antropologicznych Buchowski wymienia także: studia pozapolskie, $w$ tym europejskie, antropologię medyczną, badania płci kulturowej, antropologię polityczną, tożsamości, etniczności i migracji, studia LGBT, studia z szeroko pojętej dziedziny STS, nowocześnie ujęte kwestie dziedzictwa kulturowego (Buchowski 2017: 490).

Obszerne omówienie nurtów, orientacji i szkół funkcjonujących współcześnie $\mathrm{w}$ dyscyplinie odnajdujemy w rozważaniach $\mathrm{M}$. Filipa, który mapuje zainteresowania badawcze polskiego środowiska antropologicznego, biorąc pod uwagę zakresy tematyczne, metody badawcze, ale także inspiracje teoretyczne (filozoficzne) badaczek i badaczy, co pozwala mu na wyodrębnienie między innymi antropologii krytycznej, szkoły perspektywizmu indiańskiego Eduarda Viveirosa de Castro, szkoły latourowskiej, antropologii rzeczy, antropologii środowiska, antropologicznych studiów nad zwierzętami, antropologii fenomenologicznej, antropologii 
religii, antropologii feministycznej i gender, antropologii sensorycznej, antropologii medycyny oraz antropologii jedzenia.

We współczesnych stylach praktykowania dyscypliny uczestniczki i uczestnicy ankiety bardzo wyraźnie zaznaczają koncentrację na konkretnych zagadnieniach badawczych, co stanowi impuls do pojawiania się kolejnych antropologii przedmiotowych, nazywanych również subdyscyplinami antropologicznymi. Przedstawicielki i przedstawiciele tych nurtów nierzadko eksplorują wspólne obszary badawcze przy pomocy różnych teorii, metod, a czasem także pojęć. Jak zauważa K. Kaniowska:

Oznacza to, że zmieniły się strategie tłumaczenia zjawisk kulturowych podejmowane przez antropologów - rekonstrukcje ustąpiły pola konstrukcjom; pytanie o to „jak było", zastąpiło pytanie „jak jest”. Nie zmienił się oczywiście naczelny cel poznawczy. Jest nim nadal poszukiwanie najtrafniejszych, najbardziej przekonujących interpretacji, które pozwoliłyby zrozumieć otaczający nas świat, tj. wyjaśnić jak i dlaczego w taki właśnie sposób przebiega ludzkie doświadczenie.

Podobną diagnozę stawia antropologicznym badaniom G. Godlewski, zauważając, że „wyznacznikiem takich "niezdyscyplinowanych" orientacji (przybierających postać różnego rodzaju "studiów nad «) jest zwykle sam wybór obszaru dociekań, penetrowanego przy użyciu wszelkich dogodnych podejść, metod i narzędzi, bez względu na to, skąd są czerpane".

Rozpoznanie to podziela także A. Malewska-Szałygin, która dopowiada, iż: „W zależności od wybranego aspektu procesów kulturowo-społecznych możemy mówić o antropologii politycznej, ekonomicznej, mediów, antropologii religii i religijności, materialności, rzeczy, sztuki, antropologii wizualnej, antropologii etniczności, mobilności, migracji, miasta, globalizacji, antropologii cielesności, płci, medycyny, antropologii jedzenia i wielu innych". Podobnego zdania jest E. Tomaszewska, która dostrzega, że „ze względu na wielość kulturowych przestrzeni, które wymagają często różnych metod i sposobów opisu, antropologia kulturowa wykształca określone specjalizacje, opisujące ów »świat w kawałkach «, np.: antropologia rzeczy, miasta, obrazu, pamięci itd.".

Z analizowanych wypowiedzi wyłania się kondycja dyscypliny, którą Peter Reason i Wiliam Torbert (2010) określają jako funkcjonowanie w tak zwanej epistemologii poszerzonej, która charakteryzuje się symultaniczną koegzystencją podejść oraz kategorii badawczych wypracowywanych w historii metodologii badań jakościowych. Badania antropologiczne zyskują aktualnie status praktyk badawczych 
zorientowanych na tłumaczenie rzeczywistości przy pomocy wszelkich dostępnych metod i narzędzi oraz rozwiązywanie konkretnych problemów kulturowospołecznych. Podobna diagnoza pojawia się w rozważaniach K. Kaniowskiej, która zastanawiając się nad przyczyną tego stanu rzeczy, pisze:

Być może jest to w jakiejś mierze konsekwencja (tymczasowego?) odwrotu od poszukiwania paradygmatu; uznania, że wobec wielości nurtów i orientacji naukowych humanistyka, w tym oczywiście także antropologia, nie ma potrzeby (bo nie ma konieczności) tworzenia nowych paradygmatów, a istniejące wolno wykorzystywać bez większego lęku o konsekwencje przekraczania granic określonych teorii, koncepcji czy metod. Przeciwnie, owo przekraczanie staje się zaletą, bo zgodne jest z złożeniem o potrzebie i naukowej wartości transdyscy plinarnych, a wewnątrz dyscyplin „transnurtowych" modeli działań badawczych. Uważam, że to bardzo interesujący moment w historii antropologii. Z niedawnych sporów o tożsamość przeszliśmy do skupienia się na badaniach konkretnych fragmentów współczesnej rzeczywistości kulturowej i próbujemy tłumaczyć je wszelkimi dostępnymi i sprawdzonymi już sposobami.

$\mathrm{W}$ tak zarysowanym kontekście wciąż dyskutowanym zagadnieniem jest lokalizacja antropologii na mapie dyscyplin, a także jej sojusze i powinowactwa. Zagadnienie wyraźnego przekraczania granic dyscyplinowych, a także przenikania się i naturalnego uzupełniania pewnych aspektów uprawiania nauk humanistycznych i społecznych pojawia się w refleksji K. Kaniowskiej, M. Filipa, M. Lubasia, E. Tomaszewskiej, A. Malewskiej-Szałygin. Kaniowska zauważa, że współcześnie „zainteresowanie antropologów zwróciło się w kierunku badań subdyscyplinowych, ale sprawa definiowania własnej dyscypliny nadal jest problemem, czego dowodem jest rozpisanie niniejszej ankiety". Międzydyscyplinowy transfer metod, teorii oraz pojęć, a także zakreślanie pewnych wspólnych celów poznawczych stanowi dobrze już rozpoznaną właściwość nauk humanistycznych i społecznych. „Antropologia od dawna (by nie powiedzieć - zawsze) korzystała z koncepcji teoretycznych i metodologicznych wypracowanych przez inne dyscy pliny lub przejmowała i adaptowała na swój użytek intelektualne nurty europejskiej i amerykańskiej myśli filozoficznej czy społecznej" (Kaniowska).

Rozważania przedstawicieli dyscypliny na ten temat łączą się wyraźnie z zaznaczaniem pozytywnych aspektów, a nawet koniecznością myślenia o antropologii i osadzania jej praktyk badawczych w nurcie nauk społecznych. Argumentów na rzecz upominania się o podkreślanie społecznego wymiaru badanych zjawisk jest kilka. Jednym z nich jest tradycja łączenia w dyscyplinie jej specyfiki europejskiej 
i kontynentalnej(Buchowski, Jasiewicz, Lubaś), innym przypomnienie o badaniach rozwijanych w nurcie rodzimej antropologii społecznej, która funkcjonuje jako rozpoznawalna szkoła kojarzona z Polskim Towarzystwem Socjologicznym i działającą w jego ramach Sekcją Antropologii Społecznej (Buchowski, Jasiewicz). Potrzeba eksponowania społecznego wymiaru praktykowania antropologii stanowi istotny wątek rozważań M. Buchowskiego, który komentując jej stopniowe, jak moglibyśmy powiedzieć, oswobadzanie się z okowów etnografizmu, notuje:

Jednocześnie rozwijała się coraz bardziej dynamicznie antropologia uprawiana przez grono badaczy wywodzących się z socjologii, którzy wbrew dość powszechnym opiniom nie byli jedynie zaangażowani w odkrywanie formacji myślowej „młodego” Bronisława Malinowskiego czy też rewitalizację jego funkcjonalizmu, lecz podejmowali także wiele innych tematów. Może więc termin etno-socjo-antropologia oddawałby od tej pory sytuację bardziej adekwatnie? Pewnie tak, tym bardziej, że sięgając dalej w historii polskiej antropologii, trudno nie uwzględnić takich klasyków jak Stefan Czarnowski czy Florian Znaniecki (Buchowski 2017: 485).

Zaproponowana nazwa miałaby, zdaniem antropologa, pozwolić na uchwycenie kilku źródeł stanu przejściowego dyscypliny, który uwarunkowany był zarówno jej wewnętrzną dynamiką, nowym otwarciem uniwersytetów czasu transformacji, a zatem głębszym oddechem intelektualnym w polskich naukach społecznych i humanistycznych, jak i dobrze już rozpoznanym wpływem antropologii zachodniej, której inspiracje otwierały rodzime środowisko na nowe teorie, metody oraz perspektywy i obszary badawcze. Odnosząc się do wspomnianego czasu w historii dyscypliny, Buchowski używa jednak przede wszystkim formy 'etnoantropologia', wskazującej na koegzystowanie w niej tradycji określanych niemieckimi terminami - Volkskunde i Völkerkunde oraz dziedzictwa, które w duchu Joela Halperna i Eugena A. Hammela (1969) antropolog nazywa „antropologią tworzącą imperium i antropologią tworzącą narody".

Wydaje się jednak, że akcentowanie wagi społecznego wymiaru dyscypliny wynika przede wszystkim z potrzeby osadzania badań empirycznych, prowadzonych analiz, a także rozważań o charakterze metaantropologicznym w kontekstach kulturowo-społecznych; w tym, co aktualne, co przynależy do rzeczywistości aktorów społecznych i jest przez nich doświadczane, współtworzone i praktykowane. Zagadnienie to zostało podjęte przez J. Barańskiego, który podkreśla, iż „zakresy, teorie, metody rodzimej etnologii poszerzają się o podejścia z porządku nauk spo- 
łecznych, co jest oczywistą konsekwencją przesuwania się uwagi na zjawiska będące przedmiotem zainteresowania anthropology at home".

W odniesieniu do współczesnej postaci dyscypliny Buchowski używa nazwy 'antropologia społeczno-kulturowa', a we fragmentach, w których postuluje, by $\mathrm{w}$ badaniach antropologicznych w większym stopniu koncentrować uwagę na społecznym wymiarze zjawisk i praktyk kulturowych, stosuje formę 'antropologia społecznokulturowa', co pozwala na lingwistyczne zaznaczenie przewagi aspektu społecznego nad kulturowym. Jak wyjaśnia antropolog:

Nie chodzi, rzecz oczywista, o to, czy w dostatecznej mierze wykorzystujemy osiągnięcia brytyjskiej antropologii [...]. Rzecz w tym, że mówienie o kulturze bez uwzględniania faktu, iż jest ona wytworem społeczeństwa, odrywa ją od podłoża, z którego wyrasta. Jeśli ktoś o tym, podkreślanym w podręcznikach dyscypliny fakcie zapomina, to uprawia jednowymiarową antropologię, tropiącą idee, symbole i wyobrażenia tak, jakby to była dziedzina niezależnych od aktorów i relacji między nimi by tów. W ahistorycznym duchu historia kultury danego społeczeństwa przeradza się w historię powiązań treści, znaków i elementów światopoglądu bez uwzględnienia społecznej charakterystyki ich wyrazicieli; kultura jest traktowana jak duch oderwany od ciała. Jego całkiem groźną konsekwencją może być jednostronny „kulturalizm”, przekonanie, że kultura jest czynnikiem determinującym ludzkie działania (Buchowski 2017: 490).

W refleksjach wokół ankiety pojawiły się także wypowiedzi, w których zagadnienie to jest postrzegane $\mathrm{z}$ nieco innej perspektywy. Przykładem jest stanowisko J. Barańskiego, który odpowiadając na pierwsze pytanie, zaznacza, że w swoich rozważaniach przyjmuje

[...] nieco „zachowawczy” punkt widzenia, idąc w ślad za bodaj najbardziej rozpowszechnionym rozumieniem zakresu nauk etnologicznych (etnologii, antropologii kulturowej, antropologii społecznej, ludoznawstwa, Volkskunde, Vólkerkunde itp.), a mianowicie kultury rozumianej jako sposób życia ludzi. Wprawdzie niektórzy z uprawiających owe nauki, na przykład reprezentanci antropologii społecznej, być może nie zgodziliby się z tym rozumieniem zakresu dyscypliny, argumentując, że jest ona czymś w rodzaju socjologii porównawczej, a więc zainteresowana społeczną kondycją człowieka. Uważam jednak, że podtrzymywanie szerokiego rozumienia kultury (kultur), jako atrybutu człowieka, jest najlepszym warunkiem sine qua non uprawiania dyscypliny, służącym zarazem utrzymaniu jej odrębności w obrębie humanistyki i nauk społecznych.

Jednocześnie Barański w wyraźny, konsekwentny sposób określa współczesną dyscyplinę mianem etnologii i to właśnie jej kondycja zdaje się stanowić główną oś jego 
rozważań. W wypowiedzi badacza wprost została sformułowana potrzeba odróżniania się antropologii od pozostałych dyscyplin humanistycznych i społecznych, co stanowi pewien wyjątek w kontekście otrzymanych odpowiedzi, które diagnozują wyraźny już dzisiaj przepływ idei, myśli, teorii, narzędzi oraz metod badawczych nie tylko, co najczęściej obserwowane, w obrębie nauk humanistycznych i społecznych, ale także w zakresie współpracy na ich pograniczu z naukami kognitywnymi, biologicznymi oraz ścisłymi (Filip, Kaniowska, Lubaś).

\section{Jakie wyzwania stawia przed dyscypliną przyszłość?}

Wyzwania i powiązane z nimi zadania, jakie stawiane są przed dyscypliną, wynikają z jej wewnętrznej dynamiki; są również efektem impulsów płynących ze strony polskiej teraźniejszości. Wydaje się, że jednym z trudniejszych do zrealizowania zadań, jakie dostrzegają w przyszłości antropologii uczestnicy ankiety, jest po pierwsze, wynegocjowanie i uspójnienie nazwy dyscypliny. Po drugie, podjęcie zdecydowanych działań na rzecz zmiany jej lokowania zarówno w klasyfikacji nauk, jak i w ramach instytucji oraz usytuowanie jej w obszarze nauk społecznych. Wspomniana relokacja byłaby, zgodnie z rozpoznaniami większości uczestników ankiety, formalnym potwierdzeniem stanu rzeczy, który trwa od wielu lat.

Kolejnym, niezwykle ważnym zadaniem, jakie stawia przed dyscypliną zarówno współczesność, jak i przyszłość jest potrzeba intensywniejszego angażowania się antropolożek i antropologów w debaty dotyczące istotnych, aktualnych zjawisk, procesów oraz praktyk społeczno-kulturowych. Nie o samo debatowanie jednak chodzi; równie ważnym, jeśli nie istotniejszym zadaniem jest wzmocnienie metodologii antropologicznej w taki sposób, by temu dyskursywnemu zaangażowaniu towarzyszyła sprawczość w zakresie wpływania na postulowane zmiany, przeciwdziałania krytykowanym praktykom i wy pracowywania strategii, które przyczynią się do ich zapobiegania w różnych obszarach życia społeczno-kulturowego (Buchowski, Burszta, Jasiewicz, Lubaś, Kuligowski, Filip, Malewska-Szałygin). K. Kaniowska eksponuje ten aspekt w swoich rozważaniach na temat przyszłości antropologii i jej roli w obszarze humanistyki, przekonując:

Jeśli przewidywania te są trafne, to będziemy świadkami nowego przełomu, a mianowicie zmian w metodologii antropologii, jakie wywoła już zapoczątkowany zwrot etyczny. Bez pogłębionej etycznej refleksji nie uda się sprostać metodologicznym pro- 
blemom, jakie towarzyszą nauce wszędzie tam, gdzie ogląd badanego przedmiotu nie odbywa się z metapoziomu, ale z najbardziej bliskiej perspektywy. Z pewnością też antropologia najbliższej przyszłości nadal będzie chłonąć inspiracje płynące z całego obszaru humanistyki. Jednakże w większym stopniu będzie to dzielenie wspólnych zainteresowań i problemów, niż przejmowanie i adaptowanie koncepcji powstałych poza antropologią. Przeciwnie - toczący się już proces tzw. antropologizacji dyscyplin pokrewnych pozwala przypuszczać, że antropologia może stać się dyscypliną więcej znaczącą w humanistyce niż dotychczas. Ale taka diagnoza sprawdzi się tylko wtedy, gdy najwięcej uwagi poświęcimy refleksji metodologicznej.

Z. Jasiewicz mówi wprost o potrzebie rozwiązywania przez antropologię istotnych społecznie problemów, takich jak:

[...] różnice w przyjmowanych przez społeczeństwo wartościach, ujawniające się np. w postawach wobec świata zewnętrznego i pochodzących z tego świata obcych; nierówności w pozycji ekonomicznej i wyposażeniu kulturowym oraz potencjalnych konfliktów na tym tle; mechanizmy funkcjonowania społeczeństwa obywatelskiego, pomnażającego kapitał społeczny, rosnące zainteresowanie własnym dziedzictwem kulturowym społeczności lokalnych, regionalnych i społeczeństwa narodowego, przeciwstawiających się globalizacji; konieczność rozpoznania przez społeczeństwo narodowe świata, z którym kontakty niosą zarówno korzyści, jak i zagrożenia. Są to także wymagania rynku pracy i związana $\mathrm{z}$ nim racjonalizacja przez młodych ludzi wyboru kierunku studiów.

Powstający w tym kontekście dylemat, czy „antropolog ma być rzecznikiem zmian wiązanych z wyobrażoną przyszłością, czy obrońcą wartości łączonych z wyidealizowaną przeszłością", powinien być rozwiązywany indywidualnie przez samego antropologa. Jasiewicz sygnalizuje przy tym, iż antropolog podejmujący wybór:

[...] winien być świadomy następstwa swoich działań, które zsumowane z działaniami innych mogą prowadzić albo do nadmiernej dezorganizacji systemu społecznokulturowego albo też do jego stagnacji. Odpowiedź etnologii / antropologii kulturowej powinna obejmować stworzenie katalogu spraw uznanych za ważne społecznie, potraktowanie ich za warte kontynuacji, jeśli badania nad nimi były już prowadzone lub poszerzenie o nie przedmiotu badań.

Z referowanymi zadaniami stawianymi przed dyscypliną wiąże się postulat intensywniejszego niż dotąd uprawiania krytyki społeczno-kulturowej i praktykowania antropologii jako dyscypliny wrażliwej społecznie, historycznie i politycznie, która nie tyle opowiada się za wybranymi wartościami oraz pewnymi postawami w kontekście 
konkretnej rzeczywistości społecznej, ale bada historyczne i kulturowe warunki artykulacji oraz pojawiania się różnych postaw i wartości (zob. Marcus, Fisher 1999).

W. Burszta jako wyzwanie dla dyscypliny postrzega poruszony przez Jasiewicza problem nierówności ekonomicznej i kulturowej. Zdaniem antropologa:

Albo antropologia włączy się w krytyczną wiwisekcję neoliberalnego projektu globalnej monokultury kapitalizmu, albo jeszcze bardziej się zmarginalizuje. Zgodnie z mitem założycielskim naszej dyscypliny trzeba oddać głos słabym, nieuprzywilejowanym i tym wszystkim, którzy pozostają na marginesie głównej opowieści o współczesności. Wiedza musi mieć walor emancypacyjny, musi boleć i komplikować nasze życie, wytrącać z samozadowolenia. Takiej antropologii pragnę, o niej marzę nieustająco. [...] Jednym słowem warto wykorzystać „pierwiastek anarchistyczny”, który tkwi głęboko w antropologicznej wizji świata.

Według W. Kuligowskiego, wyzwaniem, z którym antropologia powinna się mierzyć, są zjawiska współczesne, takie jak: sieci WWW, rynki kapitałowe, nowe formy władzy, prawa, wymiany własności, pokrewieństwa. Trzeba być, podkreśla „aktywnym, sprawczym i frapującym dla innych. W przeciwnym wypadku najpierw zabraknie studentów, potem funduszy, a wreszcie akceptowalnej dla innych racji wyjaśniającej nasze dyscyplinarne istnienie". W kontekście dydaktyki antropologicznej wyzwanie to wiąże się z celem, by nie tylko kształcić studentów „na najwyższym poziomie w zakresie poznawania rzeczywistości, ale także przygotować do podejmowania badań nad problemami istotnymi lokalnie i ponadlokalnie oraz prezentowania ich społeczeństwu" (Jasiewicz).

M. Buchowski zwraca uwagę, iż współczesne wyzwania określają dawno ukształtowane pryncypia antropologii. Jak podkreśla, kierując się dziś założeniem o jedności i równości wszystkich ludzi, należy wyzbyć się infantylizmu moralnego i przeciwstawić się sprzecznym z nimi ideałom:

[...] w rodzaju rasizmu przystrojonego $\mathrm{w}$ szaty kultury i nacjonalizmu zaprawionego ideologią obrony Europy, polskości i tradycji oraz podanego w przyprawie bezpieczeństwa narodowego [...]. Brak aktywnego stawiania im czoła jest niczym innym jak wyrazem rzeczonego infantylizmu, bojaźliwości i tchórzostwa, a przy okazji z pewnością nie przyniesie poznawczo wartościowych dzieł" (Buchowski 2017: 500).

W różnych wypowiedziach pojawia się wątek wpisywania się polskiej antropologii w antropologię międzynarodową; wiąże się z tym postulat, najwyraźniej sformułowany przez Buchowskiego, by dyscyplina stawała się coraz bardziej „kosmopo- 
lityczna"; a zatem otwarta na antropologie światowe, współtworząca ich dyskursy, współpracująca z przedstawicielami dyscypliny i jej instytucjami funkcjonującymi poza krajem, angażująca się w działania międzynarodowego środowiska antropologicznego. W rzeczonej kosmopolityczności nie idzie zatem (wyłącznie) o czerpanie intelektualnych inspiracji z Zachodu, ale o włączenie się polskiej dyscypliny w międzynarodowy przepływ ludzi, myśli i idei (Buchowski 2017: 498).

W rozważaniach ankietowych wokół przyszłości dyscypliny pojawia się także rozpoznanie na temat konieczności pogłębiania krytyki źródeł, która, jak zauważa Z. Jasiewicz, nie jest $\mathrm{w}$ dyscyplinie rozwiniętą umiejętnością. Wiąże się z tym również potrzeba sięgania po nowe technologie i media pełniące rolę zarówno źródeł poznania, jak i technik ich pozyskiwania (Tomaszewska). Towarzyszy temu przekonanie o konieczności rozwijania antropologii internetu, netnografii zgodnie z założeniem, iż współczesne procesy kulturowo-społeczne „są dynamicznym połączeniem zmieniających się, różnorodnych dyskursów i praktyk realizowanych w relacjach bezpośrednich i zapośredniczonych przez technologie cyfrowe" (Malewska-Szałygin). Wyzwania komunikacyjne, jakie stawia przed dyscypliną teraźniejszość i przyszłość, odnoszą się także do potrzeby poszukiwania nowych sposobów przedstawiania wiedzy antropologicznej oraz eksperymentowania $\mathrm{z}$ formą. Z punktu widzenia kulturoznawcy, antropologia powinna poszukiwać nowych gatunków i stylów piśmiennictwa, które niełatwo jest wskazać w rodzimej dyscyplinie, co wymagałoby wypracowania „kontrtekstowości oraz pisania inaczej” (Godlewski). Jednocześnie w ankiecie pojawia się uwaga, iż wyzwania płynące ze świata wymagają od antropologów sięgania po takie formy przekazu i ekspresji, które przekraczają druk (Kuligowski).

Istotnym zagadnieniem, które wiąże się z dostrzeganymi wyzwaniami, jest uprawianie „etnologii etnologii”, systematycznej metarefleksji antropologicznej, która pozwala na przemyśliwanie kondycji dyscypliny oraz jej możliwości poznawania i diagnozowania rzeczywistości w zmieniających się kontekstach społecznych (Barański, Buchowski, Jasiewicz, Lubaś), co bywa w nieuzasadniony sposób sprowadzane do pojedynczych zaledwie nurtów, takich jak antropologia refleksyjna czy tekstualna lub, otwierając przestrzeń do polemiki, utożsamiane z fazą post-fieldwork (Filip). Uprawianie studiów z zakresu teorii antropologicznych w powiązaniu z eksponowaniem antropologicznych praktyk i obszarów badawczych może przyczynić się do uspójnienia wizerunku dyscypliny na zewnątrz; w szeroko rozumianej komunikacji społecznej. Jest także jednym ze sposobów diagnozowania i wzmacniania kapitału 
symbolicznego, który wydaje się szczególnie istotny z punktu widzenia celów i wyzwań, jakie stawiają przed antropologią jej przedstawicielki i przedstawiciele.

Jak powiada Jaques Derrida w swoim eseju-wykładzie o Uniwersytecie bezwarunkowym: „Uniwersytet powinien być miejscem, w którym nic nie uchroni się przed siłą zapytywania; nawet to, co uznaje się aktualnie za określoną figurę demokracji. Owemu zapytywaniu w takiej samej mierze podlega klasyczna idea krytyki, w znaczeniu krytyki teoretycznej, a nawet autorytet samej formy pytania czy myślenia jako zapytywania" (2015: 13). Cechą ankiety, która sprzyja inicjowaniu metarefleksji na temat dyscypliny, jest to, że rozważania antropolożek i antropologów zawarte w odpowiedziach nie uwzględniają swoich krytyk, które pozwoliłyby na osadzenie ich w odmiennych inspiracjach intelektualnych. Oczywiste jest, że wszystkie z tych uwag i propozycji otwierają przestrzeń do dyskusji i mogą być oświetlane przez rozmaite konteksty teoretyczne i światopoglądowe. Mimo pewnych różnic w sposobach definiowania, a zatem rozumienia antropologii, a także jej zadań i celów w opublikowanych poniżej rozważaniach wokół pytań ankiety bardzo wyraźnie wybrzmiało przekonanie, że antropologia powinna być krytyczną, kosmopolityczną dyscypliną, która szanuje różnicę, ale nie zgadza się na jej esencjalizowanie; dostrzegając i badając podobieństwa w różnych przestrzeniach rzeczywistości społeczno-kulturowej. Przyszłość antropologii to bycie dyscypliną zdolną do uprawiania krytyki refleksyjnej, adekwatną do tego, co aktualne; jej zadaniem jest bardziej analiza i tłumaczenie źródeł, przebiegów i okoliczności pojawiania się w rzeczywistości społeczno-kulturowej określonych sposobów jej praktykowania i artykulacji, aniżeli sprowadzanie ich do naukowego konsensusu (zob. Fortun 2017). Antropologia przyszłości to dyscyplina, która ma w sobie imperatyw pobudzania społeczeństw i kultur, edukowania ich do współtworzenia społeczeństw otwartych, świadomej refleksyjnej krytyki zastanych systemów, zjawisk i praktyk społecznych. Jak podkreśla Z. Jasiewicz: „przyszły kształt dyscypliny będzie wypadkową warunków, w których jej przyjdzie działać oraz jej potencjału, którego najważniejszym dobrem są etnologowie/antropologowie z ich umiejętnościami poznawczymi i organizacyjnymi oraz wrażliwością społeczną". 


\section{Bibliografia}

Bourdieu, P. (2007). Szkic teorii praktyki, poprzedzony trzema studiami na temat etnologii Kabylów (przeł. W. Kroker). Kęty: Wydawnictwo Marek Derewecki.

Brocki, M. (2013). Antropologia społeczna i kulturowa w przestrzeni publicznej. Problemy, dylematy, kontrowersje. Kraków: Wydawnictwo Uniwersytetu Jagiellońskiego.

Buchowski, M. (2017). Antropologia polska: genealogie, trajektorie i etyczne powinności. Lud, 101.

Červinková, H., Gołębniak B.D. (red.). (2010). Badania w działaniu. Pedagogika i antropologia zaangażowane. Wrocław: Wydawnictwo Naukowe Dolnośląskiej Szkoły Wyższej.

Derrida, J. (2015). Uniwersytet bezwarunkowy (przeł. K.M. Jaksender). Kraków: Wydawnictwo Eperons Ostrogi.

Eriksen, T.H. (2013). Etniczność i nacjonalizm. Ujęcie antropologiczne (przeł. B. Gutowska-Nowak). Kraków: Wydawnictwo UJ.

Fiske, J. (2010). Zrozumieć kulturę popularną (przeł. K. Sawicka). Kraków: Wydawnictwo Uniwersytetu Jagiellońskiego.

Fortun, K. (21012). Ethnography in late industrialism, W: O. Starn (red.), Writing culture and the life of anthropology, ss. 119-136. London: Duke University Press.

Foucault, M. (1984). What is Enlightenment? W: P. Rabinow (red.), The Foucault reader, ss. 32-50. New York: Pantheon Books.

Hannerz, U. (2013). Diversity is Our Business, W: H. Jebens, K-H. Kohl (red.), The End of Anthropology, ss. 177-202. Wantage: Sean Kingston Publishing.

Halpern, J., Hammel, E.A. (1969). Observations on the Intellectual History of Ethnology and other Social Sciences in Yugoslavia. Comparative Study in Society and History, 11 (1), 17-26.

Keesing, R.M. (1989). Exotic readings of cultural texts. Current Anthropology, 30 (4), 459-479.

Marcus, G.E. (1998). Ethnography through Thick and Thin, Princeton: Princeton University Press.

Marcus, G., Fischer, M. (1999). Anthropology as cultural critique: An experimental moment in the human sciences. Chicago: University of Chicago Press.

Pomieciński, A., Sikora, S. (red.).(2009). Zanikające granice. Antropologizacja nauki ijej dyskursów. Poznań: Biblioteka Telgte.

Rabinow, P. (2003). Anthropos today. Reflections on modern equipment. Princeton: Princeton University Press.

Rakowski, T. (red.). (2013). Etnografia/animacja/sztuka. Nierozpoznane wymiary rozwoju kulturalnego. Warszawa: Narodowe Centrum Kultury. 
Rakowski, T., Malewska-Szałygin, A. (red.). (2011). Humanistyka i dominacja. Oddolne doświadczenia społeczne w perspektywie zewnętrznych rozpoznań. Warszawa: Instytut Etnologii i Antropologii Kulturowej Uniwersytetu Warszawskiego.

Reason, P., Torbert, W. (2010). Zwrot działaniowy. Ku transformacyjnej nauce społecznej (przeł. M. Lavergne). W: H. Červinková, B.D. Gołębniak (red.). Badania w działaniu. Pedagogika $i$ antropologia zaangażowane, ss. 117-152. Wrocław: Wydawnictwo Naukowe Dolnośląskiej Szkoły Wyższej.

Sokolewicz, Z. (1981). Etnografia - Etnologia - Antropologia kultury - Ludoznawstwo. Czym sa?? Dokąd zmierzają? (Odpowiedzi na Ankiete)). Polska Sztuka Ludowa, 35 (2), 78.

Stomma, L. (1981). Etnografia - Etnologia - Antropologia kultury - Ludoznawstwo. Czym są? Dokąd zmierzają? (Odpowiedzi na Ankietę). Polska Sztuka Ludowa, 35 (2), 67. 
